\title{
Stretching the truth or lying? \\ The independence of the "independent" directors
}

\author{
Rafel Crespi * \\ rafel.crespi@uib.es
}

\author{
Bartolomé Pascual-Fuster * \\ tomeu.pascual@uib.es
}

\footnotetext{
* Departament d'Economia de l'Empresa, Universitat de les Illes Balears, Cra. de Valldemossa km 7.5, 07122 Palma (Illes Balears), Spain
}

First version: January 2013 


\title{
Stretching the truth or lying? \\ The independence of the "independent" directors
}

\begin{abstract}
The paper analyzes the misclassification of directors by firms as independent when strictly they are not. We find that independent directors, as declared by firms, represent $32.5 \%$ of the board. A filter of eight independence criteria based on publicly available information for a panel of Spanish firms, reduces the proportion to a $14,2 \%$ of strictly independents. This misclassification is especially relevant in the delegated committees' composition and chairs, as the audit committee. We find that firms controlled by managers, with dispersed ownership, have misclassification rates significantly larger than firms with large controlling owners. This gives partial support to the managerial power approach incentives to misclassify independents.
\end{abstract}

Key words: Board independence, corporate governance, director's misclassification, boards committees.

JEL classification: G30, G34, K22 


\section{Introduction}

Independent directors are alleged to minimize the potential opportunism of management and controlling shareholders in a principal agent setting. In the Anglo-American dispersed ownership context independents are key members of the board to avoid managerial misappropriation. In the continental European concentrated ownership setting, a role assigned to independent directors is to limit the extraction of private benefits by controlling large shareholders, who usually appoint the remaining members of the board of directors. The underlying fundamental is that the monitoring activity of boards depends on the effective task of their independent members. This view is widely accepted in the academic world (Bhagat and Black, 2002, Dyck and Zingales, 2004, Hermalin and Weisbach, 2003, Adams and Ferreira, 2007, Adams et al., 2008) as for the regulations as the OECD Principles of Corporate Governance of 2004; The Commission of the European Communities Recommendation ${ }^{1}$; final corporate governance rules of the New York Stock Exchange approved on November 25, 2009, and almost all existing corporate governance codes or guidelines.

Nowadays most companies, following best practices codes and guidelines, report increasing proportions of independents among their board members (Gordon, 2007, Linck et al., 2009). Rating agencies also account for the presence of a qualified number of independent directors as an element in their rating outputs, as Santella et al. (2006) report. A long time perspective of the changing trend of executives and independents on US boardroom, by Gordon (2007), show as from 1950 to 2005 the average percentage of independent directors has risen from $20 \%$ to levels above $70 \%$.

Our paper tries to answer the following questions about independents in boards: is possible to measure strictly independency of directors according to the usually accepted definitions with objective public information? To what extent do firms deviate in their classification of independent directors from the strictly ones? Which are the consequences of this misclassification of independence on boards? Which are the firm characteristics that determine the observed level of misclassification?

The roles of independent directors range from "advising and policing the board on strategic decisions” as Fama and Jensen (1983) assert, to solve potential conflicts of interest between managers and shareholders, or between controlling and minority shareholders. Effectively, European Commission Recommendation of 15 February 2005 assert that independent directors

\footnotetext{
${ }^{1}$ The Commission of the European Communities Recommendation of 15 February 2005, on the role of non-executive or supervisory directors of listed companies and on the committees of the supervisory board.
} 
play a role both in dispersed ownership companies, where the concern is how to make managers accountable to shareholders, as in companies with large controlling shareholders, to account for the interests of minority shareholders.

The relevance and the role of independent board members has been addressed in the empirical research literature usually measuring how many directors are said to be independent (e.g. Kim et al, 2007, Boone et al, 2007, Coles et al, 2008, Linck et al, 2008, Duchin et al, 2010). No question about the quality of their independence is the rule in these papers. However, a few papers address this qualitative aspect of the independence of the board of directors. Independent directors who joined the board after the CEO, are assumed to be less independent in Core et al. (1999), and in Coles et al. (2010). Santella et al. (2006) quantify the extent to which corporate disclosure for the financial year 2003 allows for verification of the independence of directors formally identified as independent by the 40 Italian blue chips. Santella et al. (2007) extend the previous descriptive results comparing financial and non financial firms in terms of ownership structure. Byrd et al. (2009) examine a more behavioral definition of director independence to exclude problematic directors, which are unlikely to stand up to management, to test their impact on firm performance and management compensation. Hwang and Kim (2009) analyze social independence between independent directors and the CEO, and the implications for CEO compensation, pay performance sensitivity and turnover. Finally, Cohen et al. (2012) analyze firms appointing independent directors who are overly sympathetic to the management.

Our contribution to the knowledge of the strict board independence, their consequences and the determinants is threefold: first, based on the best practices' codes definitions of independent directors, we provide a testable set of eight formal independence criteria and we make it operational for a panel of Spanish listed companies. We directly evaluate the strict independence of every declared independent director. Second, we derive the implications of independent directors' misclassification for the main board committees' independence. Third, we test a model to disentangle the incentives that firms might have to misclassify independent directors. Providing insights on the characteristics of the companies that misclassify their independent directors, this behavior is explained by two alternative sets of incentives: one draws on firm institutional characteristics (endogenously determined misclassification) and the second is the result of managers or blockholders potential opportunistic behavior through several corporate governance practices.

The paper begins with a discussion of Independent boards' recommendations in codes of good governance and related literature. Next section looks into the rules and recommendations about what should be an independent director. Section 4 measures the director's independence and the 
consequences on committees. Section 5 discusses the incentives and characteristics of the firm misclassification, estimating the empirical models. Section 6 concludes.

\section{Independent directors in codes of good governance and the literature}

An increasing number of corporate governance codes all over the world propose explicit recommendations on board of directors' structure, and more specifically, on the desirable proportion that independent directors should hold. Aguilera and Cuervo-Cazurra (2009) report 196 distinct codes issued by 46 countries from the 1978 first code, through the relevant 1992 UK Cadbury Report up to middle of 2008. They assert that most codes have recommendations on six governance practices, explicitly or implicitly, and the first is on the balance of executive and non-executive directors, such as independent non-executive directors.

Corporate governance rules of the New York Stock Exchange approved by the SEC on 2003 (amended on 2009), and codified in Section 303A of the NYSE's Listed Company Manual, have as first rule: "Listed companies must have a majority of independent directors". The justification is that "Effective boards of directors exercise independent judgment in carrying out their responsibilities. Requiring a majority of independent directors will increase the quality of board oversight and lessen the possibility of damaging conflicts of interest”.

Indeed the proportion of independent directors is rising over time. Gordon (2007) document for the US that independent directors rise from approximately 20\% in 1950 to $75 \%$ in 2005, arguing that the focus in shareholders' value and stock market prices contribute to such increase. More recently Linck et al. (2009) show how the Sarbanes-Oxley act in the US increased substantially the presence of independents, and that a substantial (although lower) increase is also detected in firms where this act is not mandatory. However, even if the literature analyzing the influence of the independent directors on the companies' behavior or performance is extensive, it is not conclusive. From the one hand there are studies supporting positive outcomes, such as Byrd and Hickman (1992) who show a positive relation between independent outside directors and shareholders' interest. Cotter et al. (1997) find as shareholders wealth increases during tender offers with larger proportion of independent directors on the board. Weir and Laing (2000) report for the UK better corporate governance practices when independent directors play an important role. Benkel et al. (2006) find that a large proportion of independents on the board (and in the auditing committee) reduces the level of earnings management, especially for large firms.

On the other hand, studies like Agrawal and Knoeber (1996) find empirical evidence of a negative relation between the proportion of independent directors and the firms' performance. 
Dalton et al. (1998) do not support significant relationship among financial performance and board composition. In the same direction Bhagat and Black (2002) find no correlation between measures of long term performance and independent directors on the board. Ferris and Yan (2007) found no relation between board independence and performance nor fund scandals in mutual funds after the SEC changes in the corporate governance rules of these firms. More recently Bhagat and Bolton (2009) find a negative and significant relationship between board independence and operating performance previous the Sarbanes-Oxley Act. Although, after that passage, the relationship found is positive and significant.

Several theoretical developments try to provide a better understanding of the role played by board independence, developing what can be told an optimal board independence theory (Hermalin and Weisbach, 1998, Raheja, 2005, Adams and Ferreira, 2007, Harris and Raviv, 2008, Kumar and Sivaramakrishnan, 2008). This theory shows that board independence is not always in shareholders' interest, and provide an explanation for some of the apparently conflicting empirical evidence found on the role of board independence for shareholders interest. More specifically, Hermalin and Weisbach (2003) show that past performance is a determinant of optimal board independence. In well performing firms it is optimal for shareholders' interest to allow boards with less independent directors. Some empirical papers on board composition provide evidence consistent whit the optimal independence theory (e.g. Link et al., 2008, Boone et al., 2007, Coles et al., 2008). In addition, the literature that takes care of the endogeneity problem, find that board independence is worth for shareholders' interest when it fits with the results of the optimal board independence theory. These findings are supported by Duchin et al. (2010) who analyze the effect of regulatory modifications regarding board independence, or by Nguyen and Nielsen (2010) who analyze the effect of sudden deaths of independent directors. With different methodology, using laboratory experiments, Gillette et al., (2003) support that board independence is worth for shareholders' interest even when non informed independent directors are present.

However, in order to empirically get the impact of board independence, the first step is to measure board independence accurately. Our paper connects with this literature by measuring empirically the strict independence level, approaching to the real level of independence. Our approach relies on the formal independence criteria, different from the informal independence criteria, such as social ties in Hwang and Kim (2009), or excluding as independents the directors involved in scandals in previous years in Byrd et al. (2009). Unlike Santella et al. (2006, 2007) that analyze whether disclosure is sufficient to corroborate the declared independence by firms, our formal independence approach applies to all directors in a explicit and measurable way. 
This approach will allow us explaining why some companies are more prone to misclassify directors as independents than others.

\section{What should an independent director be?}

The observed number of independent board directors comes from the firm self-classification of directors, when filling the required forms according their country legislation or disclosing their corporate governance report. For instance, in the UK, the Corporate Governance Code, the provision B.1.1s specifies: "The board should identify in the annual report each non-executive director it considers to be independent. The board should determine whether the director is independent in character and judgment and whether there are relationships or circumstances which are likely to affect, or could appear to affect, the director's judgment”.

The comparison of corporate governance codes by Aguilera and Cuervo-Cazurra (2009) points out that the definitions of independent director change across countries, even across firms. This heterogeneity is also present in the definition that international bodies and most regulators propose as independent directors' characteristics. Table 1 shows four proposals about what an independent director should be and, more specifically, what an independent should not be. These proposals come from the NYSE Listed Company Manual (amended November 25, 2009), the European Union Commission recommendation of 15 February 2005 on the role of nonexecutive directors, the UK Corporate Governance Code form 2012, and the Spanish Unified Good Governance Code form 2006.

\section{[Insert table 1]}

\section{Measuring director's independence empirically}

Under the Spanish regulation, since 2004, listed companies have to release an annual report on corporate governance practices (ARCG) to the CNMV, the Spanish securities and exchange commission. The report is standardized and filled electronically and publicly available at the CNMV web page. The report includes information about the board of director's names and their typology according the companies judgment. Specifically distinguishes executives, proprietary directors, independent directors and others. The ARCG also includes information on the board members relationship with significant shareholders, with the firm, its associates and subsidiaries.

With the information contents of the ARCG we are able to test eight independence criteria for any director declared as independent. These criteria are based on the definitions shown in Table 1 , specifically those that refer to what an independent director should not be. The first is based 
on the rule that a nomination committee is necessary to guarantee independence on the new and renewed board members. Shivdasani and Yermack (1999) find empirical evidence of CEOs involvement in appointments of new directors when no nomination committee exist, yielding more gray, non-strictly independent, directors with conflicts of interest. Best practices codes include the recommendation of having this committee, with tasks as the independents' appointment. Furthermore, since 2007 the Spanish corporate governance code states that nomination by this committee is compulsory to classify a director as independent. A limited tenure is the second criteria, which is included in the UK combined code and the EU recommendations. The third criteria restricts independence to those that don't have significant business relationship with the company. The relationship with the controlling shareholders is a key element that NYSE rules and other codes define as essential for the independence of directors, so being a director, a manager or employee of a significant shareholder ( $4^{\text {th }}$ criterion), having any (other) kind of relevant relationship with a significant shareholder ( $5^{\text {th }}$ criterion) or being paid by the company, its subsidiaries or its associates, for other functions apart from the directorship ( $6^{\text {th }}$ criterion) do not bring the qualification of real independent member. Companies can be formally board members, through a representative, and our $7^{\text {th }}$ criterion obviously restricts this kind of directors as independents. Our last criterion, the $8^{\text {th }}$, avoids classifying as independents those that formerly were executives. Table 2 summarizes these criteria.

\section{[Insert table 2]}

Our data set consists of 752 firms/year observations ranging from 2004 up to 2009. This six year dataset includes all listed firms in the Spanish Stock Market, ranging from 118 to 135 depending on the year. Information about board composition, corporate governance practices and individual information on board members, as tenure or their relationship with significant shareholders, comes from the standardized ARCG that firms have to fill. The modified code introduced a mandatory definition of an independent director. Financial information comes from the Bolsa de Madrid (Madrid Stock Exchange, the main location of the Spanish Stock Market) and Thomson Financial database.

Table 3 describes the most relevant statistics of board independence of the Spanish listed companies. From Panel A we see that the firms declared average of $32.5 \%$ independent directors on the board decreases to a $14.2 \%$ after filtering the eight independence criteria described in Table 2. The misclassification affects all industrial sectors and all firms sizes, even the largest firms, included in the Ibex35 index. Indeed, 69.81\% of firms misclassify independent directors, and most of the Ibex35 firms $(84,4 \%)$ misclassify too. The criterion that brings more 
misclassification is the first one, that refers to directors not being promoted or appointed by the nominating committee that leads the declared $32.5 \%$ of independents to a $20.3 \%$ of strictly independent directors.

\section{[Insert Table 3]}

Panel B of Table 3 provides a time perspective where the misclassification has declined substantially since 2004. While the proportion of declared independent directors remains constant around one third of the board seats, the correctly assigned, according our criteria moves from $8.3 \%$ in 2004 up to a $20.5 \%$ in 2009 , and the percentage of firms with misclassified independent directors decreased from 79.7\% in 2004 to 61.3\% in 2009. Since 2007 a new standardized format of the ARCG motivates the observed reduction of misclassification, when a explicit and mandatory definition of independent director is required.

A robustness check to know to what extent the findings are not driven by the stock of directors, appointed when independent director's appointments were less rigorous, is to analyze the pattern of new independent directors appointed every year. Table 4 shows the number of new independent directors appointed from 2005. The shift in the level in 2007 is consistent with the mentioned new mandatory definition of independent director. The large proportion of misclassified independent directors in 2009, almost one third, shown in Table 3, when compared to the $16,5 \%$ of misclassification for new appointed members in 2009 suggests that the attention is on the new appointments rather than the existing ones.

\section{[Insert Table 4]}

\subsection{The impact of independent directors misclassification: board committees}

The wide spread misclassification of independent directors among firms of all industries and sizes has an impact on the composition of the board committees with supervisory functions. Nguyen and Nielsen (2010) show as that the contribution to the firm value by independent directors is bigger when they perform relevant roles in the board committees, especially in the audit committee. Hence the supervision task is potentially affected by the misclassification of independent directors.

\section{[Insert Table 5]}

Under the Spanish Securities and Market Law all listed firms must have an audit committee. The Spanish corporate governance code recommends to have a nomination and remuneration committee (75.4\% of firms had it in 2004 , and this percentage rose up to $95 \%$ in 2009 , with a high increment in 2007). The best practices code also recommends that these committees should 
be chaired by an independent director, formed by a majority of them, with no executives in place. Table 5 shows as the average percentage of declared independent directors in both commissions is substantially higher than the percentage of independents on the board (around one half versus one third). However, once filtered the misclassified directors, these percentages decrease significantly. The declared average of $49.4 \%$ and $50.4 \%$ of independent members in the audit and in the nomination and remuneration committee respectively, falls to $21.2 \%$ and $24.1 \%$ of strictly independents. As the composition of the board of directors, the rate of misclassified independents on the committees is decreasing along time, although the figures in 2009 are still far from the 50\% of independents once misclassified independents are removed (Table 5). The majority of firms appoint for the chair of both committees a declared independent director, although only for less than one third of firms these chairs are for strictly independent directors. These proportions remain for the 2009, the most recent year in the sample, and one third of firms have misclassified independent directors chairing these committees, and one sixth have simultaneously a misclassified independent in both committees. ${ }^{2}$ These findings remain relevant in firms of all sizes and industry activities.

\section{Firms' misclassifying independent directors: incentives and characteristics.}

The analysis of the characteristics of firms with misclassified independent directors aims to understand the motivation to declare independents when they really are not. The decision to appoint independent directors is one of a variety of corporate governance mechanisms that interact, complement or substitute one another. According to Aguilera and Jackson (2010), and Rediker and Seth (1995) corporate governance mechanisms do not exist in isolation; rather they are effective when the firms' contingencies such as structure, size, industry or strategic goals are taken into account. A bundle of corporate governance practices and the specific firm ownership structure defines in our case the relevant aspect that are able to determine the number of strictly independent board members and the number of declared independents.

The codes' provisions recommending the specific proportion of independent board members to carry out supervisory tasks and management monitoring while protecting minority shareholder's interests does not affect all firms equally. When large block-holders are in place, their ability and incentives to monitor managers does not necessarily require the same amount of independent members that minority shareholders would require in dispersed ownership firms on their best interest. Consequently, the firms' willingness to comply with the recommendation of a

\footnotetext{
${ }^{2}$ From non-tabulated data, available upon request. Furthermore, in the appendix (Tables 1A to 4A) it is shown that as for the full board of directors, the lack of proposal by the nomination and remuneration committee is the main criterion of directors' misclassification, in its composition and in its chair position, in bot committees.
} 
specific proportion of independent directors depends upon the ownership structure. Misclassification of independent directors is, in this context, an option.

An additional reason that the literature reports is that the regulation driven by scandal or crisis tends to be highly strict (Larcker, et al 2011). Hence firms, intending to avoid a more restrictive regulation, analyzing the cost and benefits of complying the specific recommendations, have incentives to declare the recommended level of independents on boards. Moreover, the lack of specific enforcement structures, in a context where shareholders' advocates and regulators promote higher number of independents, could explain the incentives to misclassify.

In this context, the managerial power approach by Bebchuk et al. (2009) suggest that some combination of corporate governance practices, as their entrenchment index, provide CEO bargaining power against shareholders or power against minority shareholders in ownership dispersed firms. The average ownership of the largest shareholder is expected to relate negatively with the firm misclassification of independent directors if blockholders do not use the power to extract rents through board control from minority shareholders, and positive otherwise.

The bylaws of companies may restrict the voting rights, and power, of shareholders. Detecting firms with voting caps that set up a maximum in the number of votes a shareholder may exercise regardless of the number of shares facilitates management entrenchment. Hence we expect that these firms will have independents' misclassification more frequently. In firms where the CEO chairs the board, the concentration of power is also in line with the use of this power to appoint non-strictly independent directors. The literature relates board size with coordination problems Yermak (1996), and the larger the number of busy directors, with three or more directorships, as Fich and Shivdasani (2006) assert also empower executive directors. Similarly, firms with interlocked executive directors empower them against shareholders, as Hallock (1997) show. All firms with these governance characteristics are expected to appoint non-strictly independent directors more frequently.

Table 6 shows descriptive statistics of the proxies of the relevant variables. The ownership stake of the largest shareholder, in our sample is $36 \%$, accounts for the effect of ownership concentration on the CEO's power. This stake is larger than 5\% for 95\% of our observations. This figure is also highly correlated, 0.92 is the value, with the ownership stake of the three largest shareholders, and 0.84 with the stake of the five largest shareholders. Firms with voting caps were 18 in 2004 and declined up to 14 in 2009, affecting to 13\% of observations. In the sample $58 \%$ of firms have the CEO chairing the board of directors, a regular practice. 
Table 6 also reports the Pearson correlation coefficient among these variables Correlations, are significant and positive among proxies of managerial power, and negative between managerial power and shareholders control.

\section{[Insert Table 6]}

The usual controls for any systematic difference in independents misclassification related to firm's size, the industry, or year, as the information regime switch for independent directors report in 2007, are present.

\subsection{Estimation model and results}

The estimation strategy specifies two types of models: first refers to models that test the firms' decision to misclassify or not independent directors. Second type of models explain the intensity of the misclassification, for misclassifying firms, with count models of the number of nonstrictly independent directors.

For the estimation of the binary logit models, the dependent variable takes value 1 if the firm has at least one misclassified independent director. Table 7 shows the results of three logit specifications. We estimated pooled Logit models with robust standard errors clustered by firm (Hubbet-White), panel data random effects logit models, and Generalized Estimating Equations Logit models (Liang and Zeger, 1986, and Zeger and Liang, 1986) to account for any persistence in the decision to have misclassified directors along within the same firm $^{3}$. This method is equivalent to Feasible Generalized Least Squares for lineal models. All panel data models show 1000 replication bootstrap standard errors. Models 1 and 4 and 7 include the proxy of shareholders power (C1) and managerial power (CEO is board chair), models 2 and 5 and 8 include the remaining corporate governance variables and practices. Since board size might proxy firms' size we also estimate models 3 and 6 and 9 without this variable as robustness test.

\section{[Insert Table 7]}

Regarding the three specification with different number of explanatory variables, Wald tests are implemented to evaluate the statistical significance of the larger sets. The null of these test is that the extra variables of the larger set are simultaneously not statistically significant. These hypothesis are nor rejected (see Table 7), rendering the simplest model as the best one. Probit models have been also estimated and generate the same results. Results are robust when C3 specifications is used instead of C1.

\footnotetext{
${ }^{3}$ See Ballinger (2004) for a description of this method in organizational research.
} 
The estimation strategy of the count models of the number of non-strictly independent directors addresses to all firms (Table 8) although alternative specifications have been checked only for firms that misclassify at least one independent director, as robustness check. We estimate a pooled Poisson count model with robust standard errors clustered by firm (Hubbet-White), then we estimate random effects and fixed effects Poission count models to capture the firms' heterogeneity. The count variables are highly stable along time, since any director classified as independent stays as independent all periods in the sample, we take this persistence with Generalized Estimating Equations (GEE, see Liang and Zeger, 1986, and Zeger and Liang, 1986) count models. In these models the error terms among the observations of the same firm are allowed to be correlated. To control the potential problem of the Poisson model due to the over dispersion of our count data, we estimate the GEE model with a negative binomial distribution allowing higher dispersion than the Poisson distribution. All panel data models show 1000 replication bootstrap standard errors ${ }^{4}$.

\section{[Insert Table 8]}

All models in Table 7 clearly show as the higher is the control by shareholders the lower is the proportion of firms misclassifying independents 5 . We also get weak empirical evidence (for the pooled Logit models) of a positive interaction among firms misclassifications and voting caps limiting the power of potential new entrant shareholders. Finally, board size is positively related to the presence of misclassified independents in models 2 and 5, capturing the firm size effect, that becomes not statistically significant. The correlation of board size and market capitalization is 0.64 in table 6. In the GEE panel data logit specification only ownership structure becomes significant to explain that firms use misclassification as governance mechanism.

The count models, those from Table 8 explaining the number of independent directors misclassified confirm the findings of the previous estimations: ownership dispersion is a powerful explanatory variable of the level of non-strictly independent directors, for any of the 5 model specifications. In this count models we correct by board size, that becomes significant, sometimes with the firm capitalization also positive and significant. The correction indicates that larger the board, larger the number of misclassified independent directors, once controlling for a bunch of corporate governance practices. Very weak is the evidence of the voting cap as a explanatory variable of misclassification, only under pooled model specification.

\footnotetext{
${ }^{4}$ See Greene (2002:740) for a detailed introduction to count models.

${ }^{5}$ Even basic statistics are consistent with this result: 497 observations (firm/year) belong to firms where the largest shareholder owns less than half of shares, in $77.4 \%$ of these observations there are non-strictly independent directors. The largest shareholder owns more than half of the shares in 255 observations and in $54.9 \%$ of them there are misclassified independent directors.
} 
In sum, our results are partially consistent with the management power approach for very specific corporate governance practices. Differences among industrial sectors in the pooled models almost disappear in the panel data models, by the nature of this specifications. Finally, a strong time effect is detected, since 2007 there is a significant lower number of firms with nonstrictly independents, probably related to the enforcement efforts of the Spanish supervisor focused on new appointments of independent directors.

Furthermore, we run a number of alternative models analyzing only firms with misclassified independents to see whether these same explanatory variables provide statistically significant differences in number of directors wrongly assigned as independents. Estimating the same set of models form Table 8, with the same corrections on the standard errors, the results do not change

In sum, although our results suggest that corporate governance variables do not fully explain the intensity of declaring misclassified independents, ownership structure is the main driver of these results, opening the door to potentially alternative explanations.

\section{Discussion}

Misclassification could be be identified, under the optimal board of independence theory, as a potential adjustment of the over recommendation of corporate governance codes (the declared level) to the optimal independence degree (the strictly independents). This would happen when the degree of recommended level of board independence by regulators and by shareholders advocates is higher than the optimal degree of independence.

Under this assumption giving power to the CEO or executives in front of shareholders would induce more independents' misclassifications. Ownership dispersion, CEO Chair duality, Voting caps, proportion of Busy non executive directors, or the percentage of interlocked directors should be positively related to independents misclassification. Effectively, according to Hermalin and Weisbach, (1998) and Boone et al, (2007) the higher is this power, the lower is the optimum level of board independence. Our findings in tables 8 and 9 where the coefficient of the largest shareholder ownership relates negatively with misclassification, and the weakly significant positive effect of voting caps are partially consistent with this approach.

Our analysis shows higher presence of misclassified independents in Basic materials and in Consumer goods sectors of activity. Raheja, (2005) and Coles et al., (2008) argue that higher monitoring costs by outsiders, he lower is the optimum level of independence, therefore misclassification should be higher in high technology and in very competitive industrial sectors. 
Board size as explanatory variable shows an ambiguous relationship with misclassification given its endogenous nature Raheja (2005) and Harris and Raviv (2008). Boone, Field, Karpoff, Raheja (2007) point out that as companies grow, boards grow in response to the increasing net benefits of monitoring and board members specialization. Under this context the level of strictly independents should be bigger, the larger is board, and the firm size. In our context the expected misclassification should be lower the larger is the board, unless managerial power weights more that optimal independence reasons, as seem to occur in our model.

In sum, the main coefficients partially support the managerial power approach that seems to drive the incentives to misclassify independents. Therefore, even without a complete analysis of the alternative optimal independence theory, the conclusion is mixing.

\section{Conclusions}

The role and relevance in the board of the independent directors depends on their ability to advise and supervise the executives' decisions. The classification of directors as independents is usually declared by their firms. In the paper we provide a testable set of eight formal independence criteria and we make it operational for a panel of Spanish listed companies to distinguish among declared and strictly independents. This difference, a misclassification measure of independent directors, is analyzed in two ways: one refers to the consequences and the second focuses on the determinants or firms' characteristics that explain this misclassification.

The consequences of misclassification are described as relevant in most committees of the board, especially in those where the proportion of independents is relevant, as the auditing and nomination and remuneration committees. Another consequence is that the majority of firms appoint for the chair of both committees a declared independent director, although only less than one third of their chairs are for strictly independent directors.

On the determinants of misclassification of independent directors we argue that firms may have two kind of incentives. One is based on the managerial power approach, where entrenched powerful CEOs desire friendly boards and influences its composition. Or similarly, where large controlling shareholders are in place, they do not want independents' external control. An alternative explanation is based on the optimal board independence theory. This theory asserts that having a large proportion of independents in the boards is not always optimal. Our alternative conjecture to the managerial power approach is that whenever the optimum level of independence is below the threshold recommended by regulators and shareholders advocates, firms have incentives to fill the gap with misclassified independents. 
We analyze the characteristics firms presenting independents misclassification and found empirical evidence consistent with both explanations (not with large shareholders version of the power approach). Further work is required to evaluate the relevance of each explanation, and it is left for future research. This is important since the consequences of our findings, with a widespread presence of misclassified independent directors, are quite different. If the managerial power approach incentive is the origin of independents misclassification there is an enforcement of rules problem in our sample. Regulators should fix it in order to reduce the agency problem independent directors are supposed to address. However, if the optimal independence theory is the cause, regulators should modify board independence rules since they push firms away from the optimal independence degree, losing shareholders wealth.

We provide several contributions to the literature on board independence. First, we directly check for formal independence while previous articles check informal independence (e.g. Hwang and Kim, 2009) or check for disclosure as to demonstrate declared independence (Santella, 2006, 2007). Second, we show the implications of independents misclassification for the composition and the chair of the supervisory committees of the board of directors. Finally, we focus our efforts on firms' incentives to misclassify independent directors. While previous literature focus their attention of the managerial power approach we also analyze the optimal independence theory incentives, and provide empirical evidence rejecting large controlling shareholders misalignment of interests in terms of board composition. 


\section{References}

Adams, R., Ferreira, D., (2007) A theory of friendly boards. Journal of Finance 62, 217-250.

Adams, R., Hermalin, B., Weisbach, M., (2008) The role of boards of directors in corporate governance: A conceptual framework and survey. NBER Working Paper 14486. http://www.nber.org/papers/w14486.

Agrawal, A., C. Knoeber, (1996) Firm performance and mechanisms to control agency problems between managers and shareholders. Journal of Financial and Quantitative Analysis 31, 377-396.

Aguilera, R. V., Jackson, G., (2010) Comparative and international corporate governance. Annals of the Academy of Management 4, 485-556.

Aguilera, R., Cuervo-Cazurra, A., (2009) Codes of Good Governance. Corporate Governance: An International Review 17, 376-387.

Ballinger, G., (2004) Using Generalized Estimating Equations for Longitudinal Data Analysis. Organizational Research Methods 7, 127-150.

Bebchuk, L., Fried, J., (2003) Executive compensation as an agency problem. Journal of Economic Perspectives 17, 71-92.

Bebchul, L., Cohen, A., Ferrell, A., (2009) What Matters in Corporate Governance? Review of Financial Studies 22, 783-827.

Benkel, M., Mather, P., Ramsay, A. (2006) The association between corporate governance and earnings management: The role of independent directors. Corporate Ownership and Control 3, 65-75.

Bhagat, S., Black, B. S. (2002) The non-correlation between board independence and long-term firm performance. Journal of Corporation Law, 27: 1231-73.

Bhagat, S., Bolton, B. (2009) J.,Sarbanes-Oxley, Governance and Performance. SSRN Working Paper. http://ssrn.com/abstract=1361815.

Boone, A., Field, L., Karpoff, J., Raheja, C., (2007) The determinants of corporate board size and composition: An empirical analysis. Journal of Financial Economics 85, 66-101.

Byrd, J., Coopermand, E., Wolfe, G., (2009). Another Look at Director Independence. IRABF $1,1-16$. 
Byrd, J., Hickman, K. (1992) Do Outside Directors Monitor Managers? Evidence from Tender Offer Bids. Journal of Financial Economics 32, 195-207.

Cohen, L., Frazzini, A., Malloy, C., (2012) Hiring cheerleaders: Board appointments of "independent" directors. Management Science 58, 1039-1058.

Coles, J., Daniel, N., Naveen, L., (2008) Boards: Does one size fit all? Journal of Financial Economics 87, 329-356.

Coles, J., Daniel, N., Naveen, L., (2010) Co-opted boards. SSRN Working Paper. http://ssrn.com/abstract=1699272.

Core, J., Holthausen, R., Larcker, D.F., (1999) Corporate governance, chief executive officer compensation, and firm performance. Journal of Financial Economics 51, 371-406.

Cotter, J., Shivdasani, A., Zenner, M., (1997) Do Independent Directors Enhance Target Shareholder Wealth During Tender Offers? Journal of Financial Economics 43, 195-218.

Dalton, D., Daily, C., Ellstrand, A., Johnson, J. (1998) Meta-analytic reviews of board composition, leadership structure, and financial performance. Strategic Management Journal 19, 269-290.

Duchin, R., Matsusaka, J., Ozbas, O., (2010) When are outside directors effective? Journal of Financial Economics 96, 195-214.

Dyck, A., Zingales, L., (2004) Private Benefits Of Control: An International Comparison. Journal of Finance 59, 537-600.

Fama, E., Jensen, M., (1983) Separation of ownership and control. Journal of Law and Economics 26, 301-325.

Ferris, S., Yan, X., (2007) Do independent directors and chairmen matter? The role of boards of directors in mutual fund governance. Journal of Corporate Finance 13, 392-420.

Fich, E., Shivdasani A., (2006) Are Busy Boards Effective Monitors? Journal of Finance 61, 689-724.

Gillette, A., Noe, T., Rebello, M., (2003) Corporate board composition, protocols, and voting behavior: Experimental evidence. Journal of Finance 58, 1997-2031. 
Gordon, J., (2007) The rise of independent directors in the United States, 1950-2005: Of shareholder value and stock market prices. Columbia Law and Economics WP No. 301. http://ssrn.com/abstract=928100.

Greene, W. (2002) Econometric Analysis. Prentice Hall, New Yersey.

Hallock, K., (1997) Reciprocally Interlocking Boards of Directors and Executive Compensation. Journal of Financial and Quantitative Analysis 32, 331-344.

Harris, M, Raviv, A., (2008) A Theory of Board Control and Size. Review of Financial Studies 21, 1797-1832.

Hermalin, E., Weisbach, M., (1998) Endogenously chosen boards of directors and their monitoring of the CEO. American Economic Review 88, 96-118.

Hermalin, E., Weisbach, M., (2003) Boards of directors as an endogenously determined institution: a survey of the economic literature. Economic Policy Review, Federal Reserve Bank of New York, 7-26.

Huber, P.J., (1967) The behaviour of maximum likelihood estimates under non-standard conditions. In Proceedings of the Fifth Berkeley Symposium on Mathematical Statistics and Probability. Berkeley. CA: University of California Press 1, 221-233.

Hwang, B., Kim, S., (2009) It pays to have friends. Journal of Financial Economics 93, 138-158

Kim, K., Kitsabunnarat-Chatjuthamard, P., Nofsinger, J., (2007) Large shareholders, board independence, and minority shareholder rights: Evidence from Europe. Journal of Corporate Finance 13, 859-880.

Kumarand, P., Sivaramakrishnan, K., (2008) Who Monitors the Monitor? The Effect of Board Independence on Executive Compensation and Firm Value. Review of Financial Studies 21, 1371-1401.

Larcker, D. F., Ormazabal, G., and Taylor, D., (2011) The market reaction to corporate governance regulation. Journal of Financial Economics 101, 431-448.

Liang, K.-Y., Zeger, S. L., (1986) Longitudinal data analysis using generalized linear models. Biometrika 73, 13-22.

Linck, J., Netter, J., Yang, T., (2008) The determinants of board structure. Journal of Financial Economics 87, 308-328. 
Linck, J., Netter, J., Yang, T., (2009) The effects and unintended consequences of the SarbanesOxley act on the supply and demand for directors. Review of Financial Studies 22, 32873328.

Mooney, C. Z., and R. D. Duval. (1993) Bootstrapping: A Nonparametric Approach to Statistical Inference. Newbury Park, CA: Sage.

Nguyen, B., Nielsen, K., (2010) The value of independent directors: Evidence from sudden deaths. Journal of Financial Economics 98, 550-567.

Petersen, M., (2009) Estimating Standard Errors in Finance Panel Data Sets: Comparing Approaches. Review of Financial Studies 22, 435-480.

Raheja, C., (2005) Determinants of board size and composition: A theory of corporate boards. Journal of Financial and Quantitative Analysis 40, 283-306.

Rediker, K.J., Seth, A., (1995) Boards of directors and substitution effects of alternative governance mechanisms. Strategic Management Journal 16, 85-99.

Santella, P., Drago, C., Paone, G., (2006) How independent are independent directors? The case of Italy. Mimeo. March 2006.

Santella, P., Drago, C., Paone, G., (2007) Who Cares About Director Independence? Mimeo. March 2007.

Shivdasani, A., Yermack, D., (1999) CEO Involvement in the Selection of New Board Members: An Empirical Analysis. Journal of Finance 54, 1829-1853.

Shleifer, A., Vishny, R., (1997) A survey of corporate governance. Journal of Finance 52, 737783.

Villalonga, B., Amit, R. (2006) How do family ownership, control and management affect firm value? Journal of Financial Economics 80, 385-417.

Weir, C., Laing, D. (2000) The performance-governance relationship: The effects of Cadbury compliance on UK quoted companies. Journal of Management and Governance 4, 265-81.

White, H., (1980) A heteroskedasticity-consistent covariance matrix estimator and a direct test for heteroskedasticity. Econometrica 48, 817-830.

White, H., (1982) Maximum likelihood estimation of misspecified models. Econometrica 50, 125. 
Yermack, D. (1996) Higher market valuation of companies with a small board of directors, Journal of Financial Economics 40, 185-211.

Zeger, S. L., Liang, K.-Y., (1986) Longitudinal data analysis for discrete and continuous outcomes. Biometrics 42, 121-130. 


\section{Table1}

\section{Definitions of Independent directors according to NYSE, EU, UK and Spain codes}

\begin{tabular}{|c|c|c|c|}
\hline $\begin{array}{l}\text { NYSE Listed Company Manual. Section } \\
\text { 303A.02 (Amended November 25, 2009) }\end{array}$ & $\begin{array}{l}\text { European Union COMMISSION } \\
\text { RECOMMENDATION of } 15 \text { February } 2005 \\
\text { on the role of non-executive or supervisory } \\
\text { directors of listed companies and on the } \\
\text { committees of the (supervisory) board }\end{array}$ & $\begin{array}{l}\text { THE UK CORPORATE GOVERNANCE } \\
\text { CODE September } 2012 .\end{array}$ & $\begin{array}{l}\text { UNIFIED GOOD } \\
\text { GOVERNANCE CODE OF } \\
\text { LISTED COMPANIES. May 19, } \\
\text { 2006. Spain }\end{array}$ \\
\hline \multicolumn{4}{|l|}{ An Independent director is } \\
\hline $\begin{array}{l}\text { No director qualifies as "independent" unless } \\
\text { the board of directors affirmatively } \\
\text { determines that the director has no material } \\
\text { relationship with the listed company (either } \\
\text { directly or as a partner, shareholder or officer } \\
\text { of an organization that has a relationship with } \\
\text { the company). }\end{array}$ & $\begin{array}{l}\text { A director should be considered to be } \\
\text { independent only if he is free of any } \\
\text { business, family or other relationship, with } \\
\text { the company, its controlling shareholder or } \\
\text { the management of either, that creates a } \\
\text { conflict of interest such as to impair his } \\
\text { judgment. }\end{array}$ & $\begin{array}{l}\text { The board should identify in the annual } \\
\text { report each non-executive director it } \\
\text { considers to be independent. The board } \\
\text { should determine whether the director is } \\
\text { independent in character and judgment } \\
\text { and whether there are relationships or } \\
\text { circumstances which are likely to affect, } \\
\text { or could appear to affect, the director's } \\
\text { judgment. The board should state its } \\
\text { reasons if it determines that a director is } \\
\text { independent notwithstanding the } \\
\text { existence of relationships or } \\
\text { circumstances which may appear } \\
\text { relevant to its determination. }\end{array}$ & $\begin{array}{l}\text { Directors appointed for their } \\
\text { personal or professional qualities } \\
\text { who are in a position to perform } \\
\text { their duties without being } \\
\text { influenced by any connection } \\
\text { with the company, its } \\
\text { shareholders or its management. }\end{array}$ \\
\hline \multicolumn{4}{|l|}{ An Independent director is not } \\
\hline $\begin{array}{l}\text { (a) The director is, or has been within } \\
\text { the last three years, an employee of the listed } \\
\text { company, or an immediate family member is, } \\
\text { or has been within the last three years, an } \\
\text { executive officer of the listed company. } \\
\text { (b) The director has received, or has an } \\
\text { immediate family member who has received, } \\
\text { during any twelve-month period within the } \\
\text { last three years, more than } \$ 120,000 \text { in direct }\end{array}$ & $\begin{array}{l}\text { (a) not to be an executive or managing } \\
\text { director of the company or an associated } \\
\text { company, and not having been in such a } \\
\text { position for the previous five years; } \\
\text { (b) not to be an employee of the } \\
\text { company or an associated company, and not } \\
\text { having been in such a position for the } \\
\text { previous three years, except when the non- } \\
\text { executive or supervisory director does not }\end{array}$ & $\begin{array}{l}\text { (a) has been an employee of the } \\
\text { company or group within the last five } \\
\text { years; } \\
\text { (b) has, or has had within the last } \\
\text { three years, a material business } \\
\text { relationship with the company either } \\
\text { directly, or as a partner, shareholder, } \\
\text { director or senior employee of a body } \\
\text { that has such a relationship with the }\end{array}$ & $\begin{array}{l}\text { (a) Past employees or } \\
\text { executive directors of group } \\
\text { companies, unless } 3 \text { or } 5 \text { years } \\
\text { have elapsed, respectively, from } \\
\text { the end of the relation. } \\
\text { (b) Those who have } \\
\text { received some payment or other } \\
\text { form of compensation from the } \\
\text { company or its group on top of }\end{array}$ \\
\hline
\end{tabular}




\begin{tabular}{|c|c|c|c|}
\hline $\begin{array}{l}\text { (A) The director is a current partner } \\
\text { r employee of a firm that is the listed } \\
\text { ompany's internal or external auditor; (B) } \\
\text { he director has an immediate family member } \\
\text { vho is a current partner of such a firm; (C) } \\
\text { he director has an immediate family member } \\
\text { vho is a current employee of such a firm and } \\
\text { ersonally works on the listed company's } \\
\text { udit; or (D) the director or an immediate } \\
\text { amily member was within the last three } \\
\text { ears a partner or employee of such a firm } \\
\text { nd personally worked on the listed } \\
\text { ompany's audit within that time. }\end{array}$ & $\begin{array}{l}\text { belong to senior management and has been } \\
\text { elected to the (supervisory) board in the } \\
\text { context of a system of workers' } \\
\text { representation recognized by law and } \\
\text { providing for adequate protection against } \\
\text { abusive dismissal and other forms of unfair } \\
\text { treatment; } \\
\text { (c) not to receive, or have received, } \\
\text { significant additional remuneration from the } \\
\text { company or an associated company apart } \\
\text { from a fee received as non-executive or } \\
\text { supervisory director. Such additional } \\
\text { remuneration covers in particular any } \\
\text { participation in a share option or any other } \\
\text { performance-related pay scheme; it does not } \\
\text { cover the receipt of fixed amounts of } \\
\text { compensation under a retirement plan } \\
\text { (including deferred compensation) for prior } \\
\text { service with the company (provided that such } \\
\text { compensation is not contingent in any way } \\
\text { on continued service); } \\
\text { (d) not to be or to represent in any way } \\
\text { the controlling shareholder(s) (control being } \\
\text { determined by reference to the cases } \\
\text { mentioned in Article } 1 \text { (1) of Council } \\
\text { Directive } 83 / 349 / E E C ~(1) \text { ); } \\
\text { (e) not to have, or have had within the } \\
\text { last year, a significant business relationship } \\
\text { with the company or an associated company, } \\
\text { either directly or as a partner, shareholder, } \\
\text { director or senior employee of a body having } \\
\text { such a relationship. Business relationships } \\
\text { include the situation of a significant supplier } \\
\text { of goods or services (including financial, }\end{array}$ & $\begin{array}{l}\text { company; } \\
\text { (c) has received or receives } \\
\text { additional remuneration from the } \\
\text { company apart from a director's fee, } \\
\text { participates in the company's share } \\
\text { option or a performance-related pay } \\
\text { scheme, or is a member of the } \\
\text { company's pension scheme; } \\
\text { (d) has close family ties with any } \\
\text { of the company's advisers, directors or } \\
\text { senior employees; } \\
\text { (e) holds cross-directorships or } \\
\text { has significant links with other directors } \\
\text { through involvement in other companies } \\
\text { or bodies; } \\
\text { (f) represents a significant } \\
\text { shareholder; or has served on the board } \\
\text { for more than nine years from the date } \\
\text { of their first election. }\end{array}$ & $\begin{array}{l}\text { their directors' fees, unless the } \\
\text { amount involved is not } \\
\text { significant. Dividends or pension } \\
\text { supplements received by a } \\
\text { director for prior employment or } \\
\text { professional services shall not } \\
\text { count for the purposes of this } \\
\text { section, provided such } \\
\text { supplements are non contingent, } \\
\text { i.e. the paying company has no } \\
\text { discretionary power to suspend, } \\
\text { modify or revoke their payment, } \\
\text { and by doing so would be in } \\
\text { breach of its obligations. } \\
\text { (c) Partners, now or on the } \\
\text { past } 3 \text { years, in the external } \\
\text { auditor or the firm responsible for } \\
\text { the audit report, over the said } \\
\text { period, of the listed company or } \\
\text { any other within its group. } \\
\text { (d) Executive directors or } \\
\text { senior officers of another } \\
\text { company where an executive } \\
\text { director or senior officer of the } \\
\text { company is an external director. } \\
\text { (e) Those having material } \\
\text { business dealings with the } \\
\text { company or some other in its } \\
\text { group or who have had such } \\
\text { dealings in the preceding year, } \\
\text { either on their own account or as } \\
\text { the significant shareholder, } \\
\text { director or senior officer of a } \\
\text { company that has or has had such } \\
\text { dealings. Business dealings will }\end{array}$ \\
\hline
\end{tabular}




\begin{tabular}{|c|c|c|}
\hline $\begin{array}{l}\text { General Commentary to Section 303A.02(b): } \\
\text { An "immediate family member" includes a } \\
\text { person's spouse, parents, children, siblings, } \\
\text { mothers and fathers-in-law, sons and } \\
\text { daughters-in-law, brothers and sisters-in-law, } \\
\text { and anyone (other than domestic employees) } \\
\text { who shares such person's home. When } \\
\text { applying the look-back provisions in Section } \\
\text { 303A.02(b), listed companies need not } \\
\text { consider individuals who are no longer } \\
\text { immediate family members as a result of } \\
\text { legal separation or divorce, or those who } \\
\text { have died or become incapacitated. } \\
\text { In addition, references to the "listed } \\
\text { company" or "company" include any parent } \\
\text { or subsidiary in a consolidated group with the } \\
\text { listed company or such other company as is } \\
\text { relevant to any determination under the } \\
\text { independent standards set forth in this } \\
\text { Section 303A.02(b). }\end{array}$ & $\begin{array}{l}\text { legal, advisory or consulting services), of a } \\
\text { significant customer, and of organizations } \\
\text { that receive significant contributions from the } \\
\text { company or its group; } \\
\text { (f) not to be, or have been within the } \\
\text { last three years, partner or employee of the } \\
\text { present or former external auditor of the } \\
\text { company or an associated company; } \\
\text { (g) not to be executive or managing } \\
\text { director in another company in which an } \\
\text { executive or managing director of the } \\
\text { company is non-executive or supervisory } \\
\text { director, and not to have other significant } \\
\text { links with executive directors of the company } \\
\text { through involvement in other companies or } \\
\text { bodies; } \\
\text { (h) not to have served on the } \\
\text { (supervisory) board as a non-executive or } \\
\text { supervisory director for more than three } \\
\text { terms (or, alternatively, more than } 12 \text { years } \\
\text { where national law provides for normal terms } \\
\text { of a very small length); } \\
\text { (i) not to be a close family member of } \\
\text { an executive or managing director, or of } \\
\text { persons in the situations referred to in points } \\
\text { (a) to (h); }\end{array}$ & $\begin{array}{l}\text { include the provision of goods or } \\
\text { services, including financial } \\
\text { services, as well as advisory or } \\
\text { consultancy relationships. } \\
\text { (f) Significant } \\
\text { shareholders, executive directors } \\
\text { or senior officers of an entity that } \\
\text { receives significant donations } \\
\text { from the company or its group, or } \\
\text { has done so in the past } 3 \text { years. } \\
\text { This provision will not apply to } \\
\text { those who are merely trustees of } \\
\text { a Foundation receiving donations. } \\
\text { (g) Spouses, partners } \\
\text { maintaining an analogous } \\
\text { affective relationship or close } \\
\text { relatives of one of the company's } \\
\text { executive directors or senior } \\
\text { officers. } \\
\text { (h) Any person not } \\
\text { proposed for appointment or } \\
\text { renewal by the Nomination } \\
\text { Committee. } \\
\text { (i) Those standing in some } \\
\text { of the situations listed in a), e), f) } \\
\text { or g) above in relation to a } \\
\text { significant shareholder or a } \\
\text { shareholder with board } \\
\text { representation. In the case of the } \\
\text { family relations set out in letter } \\
\text { g), the limitation shall apply not } \\
\text { only in connection with the } \\
\text { shareholder but also with his or } \\
\text { her proprietary directors in the }\end{array}$ \\
\hline
\end{tabular}




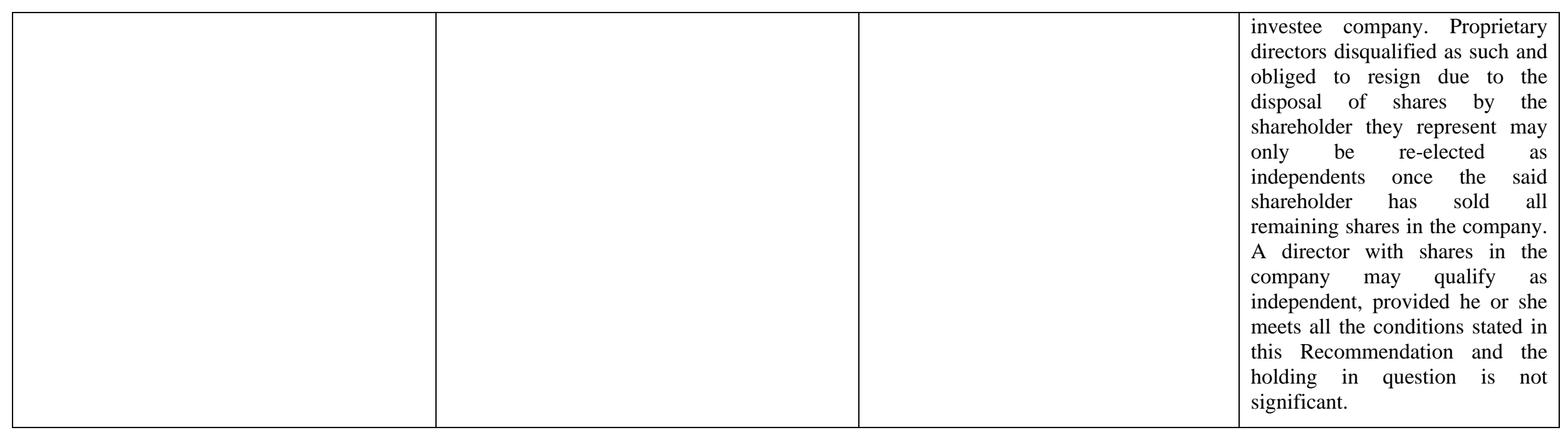


Table 2

\section{Empirical criteria to the definition of independent directors of Spanish listed firms}

[1] Proposed for appointment or renewal by the Nomination Committee ${ }^{*}$

[2] Tenure as independent director up to 12 years

[3] not to have a significant business relationship with the company

[4] not to hold a directorship, to be a manager or an employee of significant shareholder or a shareholder with board representation

[5] not to have other relevant relationship (different than those in point 4) with significant shareholder or a shareholder with board representation

[6] Not to be a director or executive in subsidiaries or associated companies

[7] Not to be a company as board director

[8] Not to be executive director in the previous year ${ }^{* *}$

* In 2007 the CNMV (the Spanish Securities and Exchange Commission) modified the information requirements regarding directors proposals. Firms must communicate who proposed each director, except for independent directors. Therefore, after 2006 we assume that all independent directors have been proposed by de Nomination committee, except when this committee does not exist, or if the director had not been formally renewed and was not promoted by this committee before 2007.

** Since we just have information from 2004, this criterion does not operate for this year. 
Table 3

\section{The independence of independent directors}

Average percentage of independent directors over board size as declared by firms in their Annual Report of Corporate Governance, and average of directors strictly independents according the 8 criteria of independence. In italics, the percentage of firms with independent directors that do not comply with the independence criteria. The independence criteria definition is from the Table 2. [1..8] refers to the results for all 8 criteria on time. The grouping by firm size is according their market capitalization as last trading day of December: Ibex35 refers to firms quoted on the stock market index. "Large" firms are those non Ibex35 with average market capitalization above $€ 1000$ Million over the last three years. Medium capitalization is for firms smaller than $€ 1000$ Million and larger than $€ 250$ Million Euro on average over the last three years. Small refers to firms with capitalizations below $€ 250$ Million Euro on average over the last three years. The industrial sector classification is of the Spanish Stock Exchange. Data for a pool of 118 firms in 2004, 119 firms in 2005, 126 in 2006, 135 for 2007, 130 during 2008, and 124 in 2009. These are all companies listed in the main trading mechanism of the Spanish Stock Exchange (SIBE).

\begin{tabular}{|c|c|c|c|c|c|c|c|c|c|c|}
\hline \multicolumn{11}{|c|}{$\begin{array}{l}\text { Average \% Independents over board size } \\
\% \text { Firms with misclassified independent directors }\end{array}$} \\
\hline & \multirow[b]{2}{*}{$\begin{array}{l}\text { Independents as } \\
\text { declared }\end{array}$} & \multicolumn{9}{|c|}{ Independetns on the Board. 8 Criteria } \\
\hline & & {$[1 \ldots 8]$} & [1] & [2] & [3] & [4] & [5] & [6] & [7] & [8] \\
\hline \multicolumn{11}{|c|}{ Panel A } \\
\hline \multicolumn{11}{|l|}{ Market Capitalization } \\
\hline \multirow[t]{2}{*}{ Ibex 35} & $39.3 \%$ & $20.0 \%$ & $29.1 \%$ & $34.1 \%$ & $36.6 \%$ & $39.1 \%$ & $38.4 \%$ & $33.6 \%$ & $39.1 \%$ & $39.3 \%$ \\
\hline & & $84.4 \%$ & $38.5 \%$ & $37.1 \%$ & $17.6 \%$ & $2.9 \%$ & $6.8 \%$ & $37.1 \%$ & $2.0 \%$ & $0.0 \%$ \\
\hline \multirow[t]{2}{*}{ Large } & $26.9 \%$ & $11.7 \%$ & $15.8 \%$ & $22.1 \%$ & $26.0 \%$ & $26.5 \%$ & $26.4 \%$ & $23.9 \%$ & $25.0 \%$ & $26.9 \%$ \\
\hline & & $61.3 \%$ & $41.7 \%$ & $35.6 \%$ & $11.0 \%$ & $4.3 \%$ & $2.5 \%$ & $25.2 \%$ & $12.9 \%$ & $0.0 \%$ \\
\hline \multirow[t]{2}{*}{ Medium } & $29.8 \%$ & $13.4 \%$ & $20.8 \%$ & $24.9 \%$ & $26.7 \%$ & $29.1 \%$ & $29.8 \%$ & $25.7 \%$ & $29.4 \%$ & $29.7 \%$ \\
\hline & & $58.6 \%$ & $35.9 \%$ & $24.2 \%$ & $7.1 \%$ & $3.5 \%$ & $0.0 \%$ & $21.7 \%$ & $3.0 \%$ & $1.0 \%$ \\
\hline \multirow[t]{2}{*}{ Small } & $32.9 \%$ & $10.8 \%$ & $14.2 \%$ & $29.7 \%$ & $32.2 \%$ & $32.3 \%$ & $32.7 \%$ & $27.7 \%$ & $31.5 \%$ & $32.8 \%$ \\
\hline & & $73.1 \%$ & $56.5 \%$ & $18.3 \%$ & $5.9 \%$ & $4.3 \%$ & $1.6 \%$ & $24.2 \%$ & $11.8 \%$ & $1.1 \%$ \\
\hline \multicolumn{11}{|l|}{ Industry } \\
\hline \multirow[t]{2}{*}{ Oil and energy } & $37.6 \%$ & $24.2 \%$ & $29.6 \%$ & $31.3 \%$ & $36.8 \%$ & $37.6 \%$ & $37.3 \%$ & $33.8 \%$ & $37.3 \%$ & $37.6 \%$ \\
\hline & & $63.1 \%$ & $40.0 \%$ & $38.5 \%$ & $3.1 \%$ & $0.0 \%$ & $4.6 \%$ & $23.1 \%$ & $3.1 \%$ & $0.0 \%$ \\
\hline \multirow[t]{2}{*}{ Materials, industry \& cons. } & $29.2 \%$ & $11.2 \%$ & $18.2 \%$ & $24.1 \%$ & $26.0 \%$ & $28.5 \%$ & $29.1 \%$ & $25.6 \%$ & $28.7 \%$ & $29.1 \%$ \\
\hline & & $70.9 \%$ & $47.3 \%$ & $33.0 \%$ & $11.5 \%$ & $3.3 \%$ & $1.1 \%$ & $28.6 \%$ & $6.6 \%$ & $0.5 \%$ \\
\hline \multirow[t]{2}{*}{ Consumer goods } & $32.1 \%$ & $12.7 \%$ & $18.3 \%$ & $27.0 \%$ & $31.4 \%$ & $31.8 \%$ & $31.9 \%$ & $26.5 \%$ & $30.6 \%$ & $32.0 \%$ \\
\hline & & $74.9 \%$ & $50.8 \%$ & $30.5 \%$ & $5.9 \%$ & $2.1 \%$ & $1.6 \%$ & $25.7 \%$ & $12.3 \%$ & $0.5 \%$ \\
\hline \multirow[t]{2}{*}{ Consumer services } & $33.1 \%$ & $13.1 \%$ & $17.4 \%$ & $29.0 \%$ & $31.2 \%$ & $32.2 \%$ & $31.1 \%$ & $27.9 \%$ & $32.7 \%$ & $33.1 \%$ \\
\hline & & $74.7 \%$ & $45.3 \%$ & $25.3 \%$ & $20.0 \%$ & $8.4 \%$ & $9.5 \%$ & $31.6 \%$ & $3.2 \%$ & $0.0 \%$ \\
\hline \multirow[t]{2}{*}{ Financial services } & $30.8 \%$ & $13.4 \%$ & $20.0 \%$ & $27.3 \%$ & $28.9 \%$ & $30.4 \%$ & $30.6 \%$ & $26.8 \%$ & $29.5 \%$ & $30.8 \%$ \\
\hline & & $62.2 \%$ & $31.4 \%$ & $23.8 \%$ & $9.7 \%$ & $3.2 \%$ & $2.2 \%$ & $24.3 \%$ & $5.9 \%$ & $0.0 \%$ \\
\hline \multirow[t]{2}{*}{ Tech. \& communications } & $48.9 \%$ & $25.8 \%$ & $33.6 \%$ & $47.1 \%$ & $44.7 \%$ & $48.2 \%$ & $48.9 \%$ & $42.1 \%$ & $48.4 \%$ & $48.2 \%$ \\
\hline & & $76.3 \%$ & $39.5 \%$ & $15.8 \%$ & $21.1 \%$ & $10.5 \%$ & $0.0 \%$ & $39.5 \%$ & $5.3 \%$ & $5.3 \%$ \\
\hline \multirow[t]{2}{*}{ Total } & $32.5 \%$ & $14.2 \%$ & $20.3 \%$ & $28.0 \%$ & $30.6 \%$ & $32.1 \%$ & $32.1 \%$ & $28.0 \%$ & $31.6 \%$ & $32.5 \%$ \\
\hline & & $69.8 \%$ & $43.0 \%$ & $28.7 \%$ & $10.5 \%$ & $3.7 \%$ & $2.8 \%$ & $27.3 \%$ & $7.0 \%$ & $0.5 \%$ \\
\hline \multicolumn{11}{|l|}{ Panel B } \\
\hline \multicolumn{11}{|l|}{ Year } \\
\hline \multirow[t]{2}{*}{2004} & $33.2 \%$ & $8.3 \%$ & $12.3 \%$ & $29.2 \%$ & $31.7 \%$ & $32.5 \%$ & $32.6 \%$ & $27.1 \%$ & $32.6 \%$ & $33.2 \%$ \\
\hline & & $79.7 \%$ & $63.6 \%$ & $23.7 \%$ & $11.9 \%$ & $5.1 \%$ & $3.4 \%$ & $32.2 \%$ & $5.1 \%$ & $0.0 \%$ \\
\hline \multirow[t]{2}{*}{2005} & $33.5 \%$ & $10.5 \%$ & $15.2 \%$ & $29.1 \%$ & $31.5 \%$ & $32.8 \%$ & $33.1 \%$ & $28.3 \%$ & $32.9 \%$ & $33.4 \%$ \\
\hline & & $78.2 \%$ & $58.0 \%$ & $28.6 \%$ & $10.9 \%$ & $4.2 \%$ & $2.5 \%$ & $31.1 \%$ & $5.0 \%$ & $0.8 \%$ \\
\hline \multirow[t]{2}{*}{2006} & $32.2 \%$ & $10.7 \%$ & $16.0 \%$ & $27.7 \%$ & $30.0 \%$ & $31.9 \%$ & $31.9 \%$ & $27.6 \%$ & $31.3 \%$ & $32.1 \%$ \\
\hline & & $78.6 \%$ & $55.6 \%$ & $32.5 \%$ & $12.7 \%$ & $3.2 \%$ & $1.6 \%$ & $28.6 \%$ & $7.1 \%$ & $1.6 \%$ \\
\hline \multirow[t]{2}{*}{2007} & $30.8 \%$ & $16.1 \%$ & $22.6 \%$ & $26.7 \%$ & $29.0 \%$ & $30.2 \%$ & $30.4 \%$ & $27.3 \%$ & $30.0 \%$ & $30.8 \%$ \\
\hline & & $60.7 \%$ & $32.6 \%$ & $26.7 \%$ & $8.9 \%$ & $5.2 \%$ & $3.0 \%$ & $23.0 \%$ & $6.7 \%$ & $0.0 \%$ \\
\hline 2008 & $32.4 \%$ & $18.4 \%$ & $26.0 \%$ & $27.8 \%$ & $30.2 \%$ & $32.1 \%$ & $32.1 \%$ & $28.3 \%$ & $31.3 \%$ & $32.3 \%$ \\
\hline & & $62.3 \%$ & $28.5 \%$ & $28.5 \%$ & $10.8 \%$ & $2.3 \%$ & $2.3 \%$ & $23.8 \%$ & $8.5 \%$ & $0.8 \%$ \\
\hline 2009 & $33.3 \%$ & $20.5 \%$ & $28.9 \%$ & $27.8 \%$ & $31.4 \%$ & $33.0 \%$ & $32.9 \%$ & $29.3 \%$ & $31.9 \%$ & $33.3 \%$ \\
\hline & & $61.3 \%$ & $22.6 \%$ & $32.3 \%$ & $8.1 \%$ & $2.4 \%$ & $4.0 \%$ & $25.8 \%$ & $9.7 \%$ & $0.0 \%$ \\
\hline
\end{tabular}




\section{Table 4}

\section{New appointed independent directors}

Number of new independent directors, as declared by firms, and the percentage of them meeting the 8 criteria of independence described in Table 2. [1...8] refers to the results for all 8 criteria on time. The grouping by size according their market capitalization is the following: companies in the Ibex35 stock market index are of December each year. "Large" firms are those non Ibex35 with average market capitalization above $€ 1000$ Million over the last three years. Medium capitalization is for firms smaller than $€ 1000$ Million but larger than $€ 250$ Million on average over the last three years. Small refers to firms with capitalizations below $€ 250$ Million on average over the last three years. The industrial sector classification is of the Spanish Stock Exchange. Data for a pool of 119 firms in 2005, 126 in 2006, 135 for 2007, 130 during 2008, and 124 in 2009. These are companies listed in the main trading mechanism of the Spanish Stock Exchange (SIBE). A new independent director is computed just if its firms was into the database in the previous year, therefore there are no new independent directors counted for 2004 and when firms enter the database.

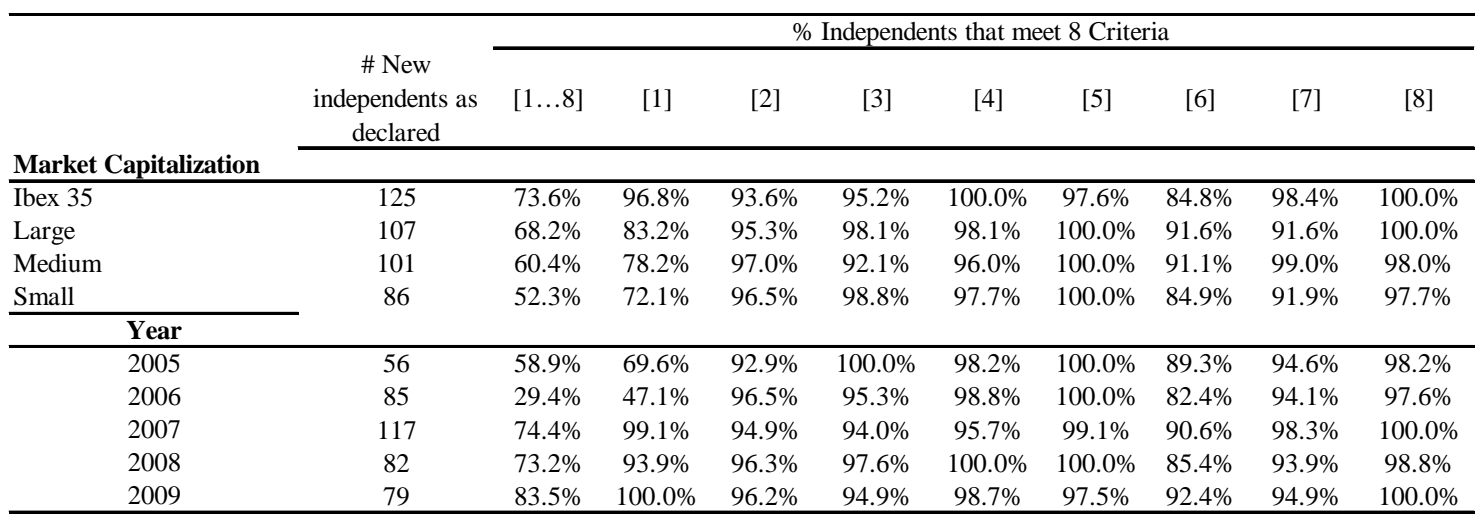




\section{Table 5}

\section{Independent directors in boards' supervisory committees}

Average percentage of independent directors in the auditing committee and in the nomination and remuneration committee of the board of directors, and percentage of firms where the chair of these committees is an independent director, as declared by firms in their Annual Report on Corporate Governance and the strictly classified according the 8 criteria of independence as described in Table 2. The grouping by size according their market capitalization is the following: companies in the Ibex35 stock market index are of December each year. "Large" firms are those non Ibex35 with average market capitalization above $€ 1000$ Million over the last three years. Medium capitalization is for firms smaller than $€ 1000$ Million but larger than $€ 250$ Million on average over the last three years. Small refers to firms with capitalizations below $€ 250$ Million on average over the last three years. Data for a pool of 118 firms in 2004, 119 firms in 2005 , 126 in 2006, 135 for 2007, 130 during 2008, and 124 in 2009. These are companies listed in the main trading mechanism of the Spanish Stock Exchange (SIBE). All firms have an auditing committee. Just 89 firms in 2004, 91 in 2005, 102 in 2006, 126 in 2007, 121 in 2008, and 118 in 2009 have a nomination and remuneration committee. ${ }^{6}$ For this committee percentages are computed just for firms having it.

\begin{tabular}{|c|c|c|c|c|c|c|c|c|}
\hline & \multicolumn{4}{|c|}{ Auditing committee } & \multicolumn{4}{|c|}{ Nomination and remuneration committee } \\
\hline & \multicolumn{2}{|c|}{ \% Independents } & \multicolumn{2}{|c|}{$\begin{array}{l}\% \text { firms with Charir } \\
\text { Independent }\end{array}$} & \multicolumn{2}{|c|}{ \% Independents } & \multicolumn{2}{|c|}{$\begin{array}{l}\text { \% firms with Charir } \\
\text { Independent }\end{array}$} \\
\hline & Declared & After $[1 \ldots 8]$ & Declared & After [1...8] & Declared & After $[1 \ldots 8]$ & Declared & After $[1 \ldots 8]$ \\
\hline \multicolumn{9}{|c|}{ Market Capitalization } \\
\hline Ibex 35 & $56.3 \%$ & $28.5 \%$ & $83.4 \%$ & $42.4 \%$ & $58.8 \%$ & $28.0 \%$ & $73.1 \%$ & $30.3 \%$ \\
\hline Large & $41.8 \%$ & $18.7 \%$ & $62.6 \%$ & $28.2 \%$ & $41.4 \%$ & $20.5 \%$ & $56.7 \%$ & $32.7 \%$ \\
\hline Medium & $47.6 \%$ & $21.3 \%$ & $68.7 \%$ & $27.8 \%$ & $49.3 \%$ & $23.7 \%$ & $61.5 \%$ & $34.8 \%$ \\
\hline Small & $50.3 \%$ & $15.4 \%$ & $70.4 \%$ & $23.7 \%$ & $49.5 \%$ & $22.8 \%$ & $61.5 \%$ & $34.8 \%$ \\
\hline Total & $49.4 \%$ & $21.2 \%$ & $71.8 \%$ & $30.9 \%$ & $50.4 \%$ & $24.1 \%$ & $64.0 \%$ & $32.9 \%$ \\
\hline
\end{tabular}

\footnotetext{
${ }^{6}$ Some variation is due to the entry and exit of firms from the sample.
} 


\section{Table 6}

\section{Descriptive statistics of firms' characteristics}

Statistics of firm's characteristics and correlation matrix for the pool of 118 firms in 2004, 119 firms in 2005, 126 in 2006, 135 for 2007, 130 during 2008, and 124 in 2009. Market Capitalization is in $€$ millions to compute its mean, median and standard deviations, and in logs to compute its correlation coefficients, C1 is the percentage of shares owned by the largest shareholder, CEO is board Chair is a dummy variable to identify firms where the CEO chairs the board of directors, \% busy non-executive directors (a director is busy if she holds a position in three or more boards of directors) is computed over board size, as it is the percentage of interlocked executive directors (those who are also non-executive director in a firm where a non-executive director of the first firm is an executive director). Voting cap is a dummy variable identifying firms with a maximum number of votes that a shareholder may exercise independently of the number of shares she has.

\begin{tabular}{|c|c|c|c|c|c|c|c|c|c|}
\hline & $\begin{array}{c}\% \\
\text { Observations } \\
\end{array}$ & Mean & Median & Std Dev & [1] & {$[2]$} & {$[3]$} & [4] & {$[5]$} \\
\hline [1] Market Cap. & & 4655.18 & 833.7 & 12074.3 & & & & & \\
\hline [2] C1 & & 36.39 & 29.54 & 26.05 & $0.0753^{* *}$ & & & & \\
\hline [3] CEO is board chair & $58 \%$ & & & & $0.1518 * * *$ & $-0.1597 * * *$ & & & \\
\hline [4] Board size & & 11.04 & 10 & 3.86 & $0.6346 * * *$ & $-0.1505^{* * *}$ & $0.101^{* * *}$ & & \\
\hline [5] Voting Cap & $13 \%$ & & & & $0.2078^{* * *}$ & $-0.2841 * * *$ & $0.1077^{* * *}$ & $0.2005^{* * *}$ & \\
\hline [6] \% Busy non-exec direcs & & 9.64 & 0 & 14.01 & $0.2593 * * *$ & $0.1582 * * *$ & -0.0258 & $0.2189 * * *$ & -0.0392 \\
\hline [7]\% Interlock exec direcs & & 12.02 & 0 & 26.2 & $-0.0715^{* *}$ & $-0.105^{* * *}$ & $0.1171^{* * *}$ & -0.0238 & -0.0024 \\
\hline
\end{tabular}




\section{Table 7}

\section{Corporate governance and independents’ misclassification}

Logit models where the positive value of the dependent variable is when a firm has a director not meeting the 8 independence criteria in Table 2. Panel A shows Pooled Logit model estimations with Huber (1967) and White (1980, 1982) robust t statistics, clustering by firm (Petersen, 2009). Panel B shows Panel data Logit estimations with random effects where t statistics are computed by bootstrap techniques with 1000 replications (Mooney and Duval, 1993). Panel C presents the GEE Poisson panel models allowing correlation among the error terms of the same firm, with 1000 replications bootstrap standard errors. The explanatory variables are the log of each firm's stock market capitalization at the end of each year, the percentage of shares owned by the largest shareholder, a dummy variable detecting firms where the CEO also chairs the board of directors, the board size, a dummy variable identifying firms where there are voting caps (a maximum number of votes that a shareholder may exercise indecently of the number of shares she has), the percentage of busy directors (a director is busy if she holds a position in three or more boards of directors), the percentage of interlocked executive directors (those who are also non-executive director in a firm where a non-executive director of the first firm is an executive director), a dummy variable for each industrial sector (Basic materials, Industry and construction, Consumer goods, Consumer services, Financial services, Technology and communications) except Oil and Energy, a dummy variable for each year except 2004, and a constant term. The constant term and the industrial sector dummy variables are omitted below. Data for a pool of 118 firms in 2004, 119 firms in 2005, 126 in 2006, 135 for 2007, 130 during 2008, and 124 in 2009. These are companies listed in the main trading mechanism of the Spanish Stock Exchange (SIBE). $\mathrm{Chi}^{2}$ is a Wald test of the statistical significance of all the explanatory variables. $\mathrm{Chi}^{2}$-II is a Wald test of the join statistical significance of Board size, Voting Cap, \% Busy non-executive directors, and \% Interlocked executive directors. Chi ${ }^{2}$-III is a Wald test of the join statistical significance of Voting Cap, \% Busy non-executive directors, and \% Interlocked executive directors. Likelihood ratio test $r h o=0$ is a test on the statistical significance of the variance of the unit-specific residual.

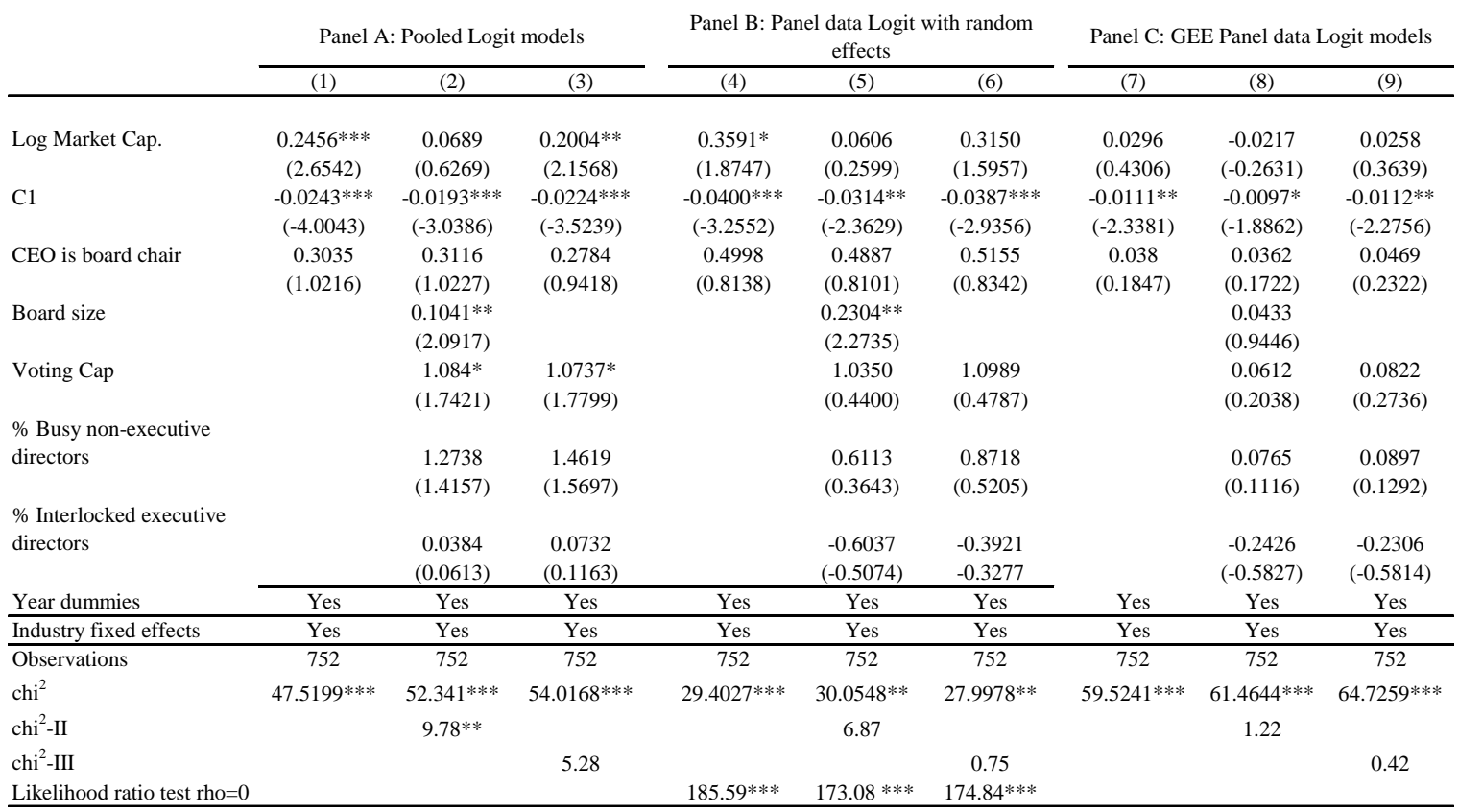

Note: $* * *$ denotes significance at the $1 \%$ level; ** denotes significance at the $5 \%$ level; * denotes significance at the $10 \%$ level 
Table 8

\section{Corporate governance and the number of misclassified independents by firm}

This table contains the estimation of models where the dependent variable is the number of misclassified independents by firm. A misclassified independent director is an independent not meeting the 8 independence criteria in Table 2. Panel A shows the estimation of pooled Poisson models, panel B provides Fixed Effects Poisson panel models, Panel C Random Effects Poison panel models, Panel D presents the GEE Poisson panel models allowing correlation among the error terms of the same firm, and Panel E the GEE Negative Binomial panel models allowing the same correlation as panel D. Pooled models show Huber $(1967)$ and White $(1980,1982)$ robust t statistics, clustering by firm (Petersen, 2009). Panel data models show t statistics computed by bootstrap techniques with 1000 replications (Mooney and Duval, 1993). The explanatory variables are the log of each firm's stock market capitalization at the end of each year, the percentage of shares owned by the largest shareholder, a dummy variable detecting firms where the CEO also chairs the board of directors, the board size, a dummy variable identifying firms where there are voting caps (a maximum number of votes that a shareholder may exercise indecently of the number of shares she has), the percentage of busy directors (a director is busy if she holds a position in three or more boards of directors), the percentage of interlocked executive directors (those who are also non-executive director in a firm where a non-executive director of the first firm is an executive director), a dummy variable for each industrial sector (Basic materials, Industry and construction, Consumer goods, Consumer services, Financial services, Technology and communications) except Oil and Energy, a dummy variable for each year except 2004, and a constant term. The constant term and the industrial sector dummy variables are omitted below. Data for a pool of 118 firms in 2004, 119 firms in 2005, 126 in 2006, 135 for 2007, 130 during 2008, and 124 in 2009. These are companies listed in the main trading mechanism of the Spanish Stock Exchange (SIBE). Three firms with just one observation are omitted in the Fixed Effects estimations. $\mathrm{Chi}^{2}$ is a Wald test of the statistical significance of all the explanatory variables. Chi ${ }^{2}$-II is a Wald test of the join statistical significance of Voting Cap, \% Busy non-executive directors, and \% Interlocked executive directors. Likelihood ratio test alpha $=0$ is a test on the statistical significance of the unit-specific residual.

\begin{tabular}{|c|c|c|c|c|c|c|c|c|c|c|}
\hline & \multicolumn{2}{|c|}{$\begin{array}{l}\text { Panel A: Pooled Poisson } \\
\text { models }\end{array}$} & \multicolumn{2}{|c|}{$\begin{array}{l}\text { Panel B: Fixed Effects } \\
\text { Poisson }\end{array}$} & \multicolumn{2}{|c|}{$\begin{array}{l}\text { Panel C: Random Effects } \\
\text { Poisson }\end{array}$} & \multicolumn{2}{|c|}{ Panel D: GEE Poisson } & \multicolumn{2}{|c|}{$\begin{array}{l}\text { Panel E: GEE Negative } \\
\text { Binomial } \\
\end{array}$} \\
\hline & (1) & $(2)$ & (3) & (4) & (5) & (6) & (7) & $(8)$ & (9) & $(10)$ \\
\hline Log Market Cap. & $\begin{array}{c}0.0253 \\
(0.5472)\end{array}$ & $\begin{array}{c}0.0076 \\
(0.1543)\end{array}$ & $\begin{array}{l}0.1705^{* *} \\
(2.5176)\end{array}$ & $\begin{array}{c}0.1767 * * \\
(2.519)\end{array}$ & $\begin{array}{l}0.0811^{*} \\
(1.8175)\end{array}$ & $\begin{array}{c}0.079 * \\
(1.7819)\end{array}$ & $\begin{array}{c}0.0669 \\
(1.5524)\end{array}$ & $\begin{array}{l}0.0643 \\
(1.484)\end{array}$ & $\begin{array}{l}0.0827^{*} \\
(1.8198)\end{array}$ & $\begin{array}{l}0.0807^{*} \\
(1.7414)\end{array}$ \\
\hline C1 & $\begin{array}{l}-0.0097 * * * \\
(-3.2502)\end{array}$ & $\begin{array}{c}-0.0076^{* *} \\
(-2.4673)\end{array}$ & $\begin{array}{l}-0.0099 * \\
(-1.9385)\end{array}$ & $\begin{array}{l}-0.0105^{* *} \\
(-2.0543)\end{array}$ & $\begin{array}{c}-0.0107 * * * \\
(-3.8805)\end{array}$ & $\begin{array}{c}-0.0102 * * * \\
(-3.4931)\end{array}$ & $\begin{array}{l}-0.0085^{* * *} \\
(-2.8868)\end{array}$ & $\begin{array}{c}-0.0077 * * * \\
(-2.5986)\end{array}$ & $\begin{array}{c}-0.0099 * * * \\
(-3.3621)\end{array}$ & $\begin{array}{c}-0.0092 * * * \\
(-2.9361)\end{array}$ \\
\hline CEO is board chair & $\begin{array}{c}0.0332 \\
(0.2324)\end{array}$ & $\begin{array}{c}0.0265 \\
(0.1987)\end{array}$ & $\begin{array}{c}-0.0316 \\
(-0.2829)\end{array}$ & $\begin{array}{c}-0.0335 \\
(-0.2861)\end{array}$ & $\begin{array}{l}0.0008 \\
(0.008)\end{array}$ & $\begin{array}{c}0.0072 \\
(0.0692)\end{array}$ & $\begin{array}{c}0.0166 \\
(0.1537)\end{array}$ & $\begin{array}{c}0.0247 \\
(0.2307)\end{array}$ & $\begin{array}{c}0.011 \\
(0.1028)\end{array}$ & $\begin{array}{c}0.0138 \\
(0.1296)\end{array}$ \\
\hline Board size & $\begin{array}{c}0.0741^{* * *} \\
(3.756)\end{array}$ & $\begin{array}{l}0.0768^{* * * *} \\
(3.6661)\end{array}$ & $\begin{array}{l}0.0822 * * \\
(2.5241)\end{array}$ & $\begin{array}{l}0.0825^{* *} \\
(2.5314)\end{array}$ & $\begin{array}{c}0.0789 * * * \\
(3.7431)\end{array}$ & $\begin{array}{l}0.0796 * * * \\
(3.7868)\end{array}$ & $\begin{array}{l}0.068^{* * *} \\
(3.3887)\end{array}$ & $\begin{array}{l}0.0703^{* * *} \\
(3.4662)\end{array}$ & $\begin{array}{c}0.0727 * * * \\
(3.3678)\end{array}$ & $\begin{array}{c}0.0739 * * * \\
(3.4393)\end{array}$ \\
\hline Voting Cap & & $\begin{array}{l}0.3863^{* *} \\
(2.3176)\end{array}$ & & $\begin{array}{c}-0.1703 \\
(-0.8)\end{array}$ & & $\begin{array}{c}0.1009 \\
(0.5328)\end{array}$ & & $\begin{array}{c}0.1336 \\
(0.7418)\end{array}$ & & $\begin{array}{c}0.1057 \\
(0.5248)\end{array}$ \\
\hline $\begin{array}{l}\% \text { Busy non-executive } \\
\text { directors }\end{array}$ & & $\begin{array}{c}-0.2709 \\
(-0.6032)\end{array}$ & & $\begin{array}{l}-0.0726 \\
(-0.1904)\end{array}$ & & $\begin{array}{c}-0.1478 \\
(-0.4694)\end{array}$ & & $\begin{array}{l}-0.1695 \\
(-0.5869)\end{array}$ & & $\begin{array}{l}-0.1732 \\
(-0.515)\end{array}$ \\
\hline $\begin{array}{l}\text { \% Interlocked executive } \\
\text { directors }\end{array}$ & & $\begin{array}{c}-0.2136 \\
(-1.0525)\end{array}$ & & $\begin{array}{c}-0.0758 \\
(-0.2545)\end{array}$ & & $\begin{array}{l}-0.0742 \\
(-0.341)\end{array}$ & & $\begin{array}{c}-0.1378 \\
(-0.5849)\end{array}$ & & $\begin{array}{c}-0.0492 \\
(-0.1941)\end{array}$ \\
\hline Y2005 & $\begin{array}{c}-0.0801 * * \\
(-2.0643)\end{array}$ & $\begin{array}{l}-0.0773^{*} \\
(-1.9435)\end{array}$ & $\begin{array}{c}-0.1086^{* * *} \\
(-2.8055)\end{array}$ & $\begin{array}{l}-0.111^{* * *} \\
(-2.8675)\end{array}$ & $\begin{array}{c}-0.0831 * * \\
(-2.1245)\end{array}$ & $\begin{array}{c}-0.0837^{* *} \\
(-2.1823)\end{array}$ & $\begin{array}{c}-0.0893^{* *} \\
(-2.3668)\end{array}$ & $\begin{array}{l}-0.0895 * * \\
(-2.3915)\end{array}$ & $\begin{array}{c}-0.0989^{* *} \\
(-2.5041)\end{array}$ & $\begin{array}{c}-0.1029 * * \\
(-2.5676)\end{array}$ \\
\hline Y2006 & $\begin{array}{l}-0.1193^{*} \\
(-1.8047)\end{array}$ & $\begin{array}{c}-0.1074 \\
(-1.5354)\end{array}$ & $\begin{array}{c}-0.1763^{* * *} \\
(-2.6256)\end{array}$ & $\begin{array}{c}-0.1847 * * * \\
(-2.7304)\end{array}$ & $\begin{array}{l}-0.1273 * * \\
(-2.1692)\end{array}$ & $\begin{array}{c}-0.1275^{* *} \\
(-2.169)\end{array}$ & $\begin{array}{c}-0.1237 * * \\
(-2.0372)\end{array}$ & $\begin{array}{c}-0.1243 * * \\
(-2.041)\end{array}$ & $\begin{array}{c}-0.1404^{* *} \\
(-2.1516)\end{array}$ & $\begin{array}{c}-0.1429^{* *} \\
(-2.156)\end{array}$ \\
\hline Y2007 & $\begin{array}{c}-0.4379 * * * \\
(-4.7148)\end{array}$ & $\begin{array}{c}-0.419^{* * *} \\
(-4.4586)\end{array}$ & $\begin{array}{c}-0.4502 * * * \\
(-4.955)\end{array}$ & $\begin{array}{c}-0.4583^{* * *} \\
(-5.114)\end{array}$ & $\begin{array}{c}-0.4072^{* * *} \\
(-4.9239)\end{array}$ & $\begin{array}{l}-0.404 * * * \\
(-4.9579)\end{array}$ & $\begin{array}{c}-0.3975^{* * *} \\
(-4.733)\end{array}$ & $\begin{array}{c}-0.3955 * * * \\
(-4.7538)\end{array}$ & $\begin{array}{c}-0.4546 * * * \\
(-5.3134)\end{array}$ & $\begin{array}{l}-0.453 * * * \\
(-5.2442)\end{array}$ \\
\hline Y2008 & $\begin{array}{c}-0.4888 * * * \\
(-5.5959)\end{array}$ & $\begin{array}{c}-0.4844 * * * \\
(-5.5279)\end{array}$ & $\begin{array}{c}-0.4124 * * * \\
(-4.9656)\end{array}$ & $\begin{array}{c}-0.4194 * * * \\
(-5.1088)\end{array}$ & $\begin{array}{c}-0.4271^{* * *} \\
(-5.265)\end{array}$ & $\begin{array}{c}-0.4284^{* * *} \\
(-5.2575)\end{array}$ & $\begin{array}{c}-0.4286 * * * \\
(-5.1234)\end{array}$ & $\begin{array}{c}-0.4316 * * * \\
(-5.147)\end{array}$ & $\begin{array}{c}-0.4934 * * * \\
(-5.6634)\end{array}$ & $\begin{array}{c}-0.4971^{* * *} \\
(-5.6358)\end{array}$ \\
\hline Y2009 & $\begin{array}{c}-0.5906 * * * \\
(-6.022)\end{array}$ & $\begin{array}{c}-0.5908 * * * \\
(-5.9795)\end{array}$ & $\begin{array}{c}-0.5425 * * * \\
(-5.7957)\end{array}$ & $\begin{array}{c}-0.5535 * * * \\
(-5.9538)\end{array}$ & $\begin{array}{c}-0.5459^{* * * *} \\
(-5.9035)\end{array}$ & $\begin{array}{l}-0.55^{* * *} \\
(-5.9423)\end{array}$ & $\begin{array}{c}-0.5438 * * * \\
(-5.6996)\end{array}$ & $\begin{array}{c}-0.5513^{* * * *} \\
(-5.7843)\end{array}$ & $\begin{array}{l}-0.604 * * * \\
(-6.3308)\end{array}$ & $\begin{array}{l}-0.609 * * * \\
(-6.3293)\end{array}$ \\
\hline Industry fixed effects & Yes & Yes & Yes & Yes & Yes & Yes & Yes & Yes & Yes & Yes \\
\hline Observations & 752 & 752 & 649 & 649 & 752 & 752 & 752 & 752 & 752 & 752 \\
\hline $\mathrm{Chi}^{2}$ & $107.8514 * * *$ & $122.6849 * * *$ & $67.7616^{* * *}$ & $78.5454 * * *$ & $110.8866 * * *$ & $118.4725^{* * *}$ & $100.241^{* * *}$ & $102.6832 * * *$ & $107.1919^{* * *}$ & $111.8955^{* * *}$ \\
\hline $\mathrm{Chi}^{2}-\mathrm{II}$ & & $8.76^{* *}$ & & 0.69 & & 0.64 & & 1.14 & & 0.54 \\
\hline $\begin{array}{l}\text { Lokelihood-ratio test } \\
\text { alpha }=0\end{array}$ & & & & & $506.99 * * *$ & $470.54 * * *$ & & & & \\
\hline
\end{tabular}




\section{APPENDIX}

\section{Table 1A}

\section{Auditing committee: Proportion of independent directors}

Average percentage of independent directors on the board of directors and in the auditing committee, as declared by firms in their Annual Report on Corporate Governance and after the 8 criteria of independence described in Table 2. The grouping by size according their market capitalization is the following: companies in the Ibex35 stock market index are of December each year. "Large" firms are those non Ibex35 with average market capitalization above $€$ 1000 Million over the last three years. Medium capitalization is for firms smaller than $€ 1000$ Million but larger than $€ 250$ Million on average over the last three years. Small refers to firms with capitalizations below $€ 250$ Million on average over the last three years. The industrial sector classification is of the Spanish Stock Exchange. Data for a pool of 118 firms in 2004, 119 firms in 2005, 126 in 2006, 135 for 2007, 130 during 2008, and 124 in 2009. These are companies listed in the main trading mechanism of the Spanish Stock Exchange (SIBE).

\begin{tabular}{|c|c|c|c|c|c|c|c|c|c|c|c|}
\hline \multicolumn{11}{|l|}{ Average \% independent directors } & Independetns in the auditing committee. 8 Criteria \\
\hline & Board & $\begin{array}{c}\text { Auditing } \\
\text { committee }\end{array}$ & {$[1 \ldots 8]$} & [1] & [2] & [3] & [4] & [5] & [6] & [7] & [8] \\
\hline \multicolumn{12}{|l|}{ Panel A: Size and Industrial Sector } \\
\hline \multicolumn{12}{|l|}{ Market Capitalization } \\
\hline Ibex 35 & $39.3 \%$ & $56.3 \%$ & $28.5 \%$ & $43.5 \%$ & $47.9 \%$ & $52.4 \%$ & $56.1 \%$ & $55.4 \%$ & $46.7 \%$ & $56.3 \%$ & $56.3 \%$ \\
\hline Large & $26.9 \%$ & $41.8 \%$ & $18.7 \%$ & $25.5 \%$ & $35.0 \%$ & $41.0 \%$ & $40.7 \%$ & $41.1 \%$ & $36.8 \%$ & $38.8 \%$ & $41.8 \%$ \\
\hline Medium & $29.8 \%$ & $47.6 \%$ & $21.3 \%$ & $30.7 \%$ & $41.7 \%$ & $43.4 \%$ & $46.6 \%$ & $47.6 \%$ & $40.9 \%$ & $47.1 \%$ & $47.2 \%$ \\
\hline Small & $32.9 \%$ & $50.3 \%$ & $15.4 \%$ & $20.5 \%$ & $45.6 \%$ & $48.9 \%$ & $49.1 \%$ & $50.0 \%$ & $41.9 \%$ & $48.8 \%$ & $50.1 \%$ \\
\hline \multicolumn{12}{|l|}{ Industrial Sector } \\
\hline Oil and energy & $37.6 \%$ & $49.6 \%$ & $32.7 \%$ & $39.6 \%$ & $39.6 \%$ & $48.8 \%$ & $49.6 \%$ & $49.6 \%$ & $42.9 \%$ & $49.6 \%$ & $49.6 \%$ \\
\hline Basic materials, industry and construction & $29.2 \%$ & $43.3 \%$ & $14.3 \%$ & $24.8 \%$ & $36.0 \%$ & $38.3 \%$ & $42.0 \%$ & $43.1 \%$ & $36.9 \%$ & $42.3 \%$ & $43.3 \%$ \\
\hline Consumer goods & $32.1 \%$ & $48.0 \%$ & $20.1 \%$ & $27.4 \%$ & $41.8 \%$ & $47.1 \%$ & $47.3 \%$ & $47.8 \%$ & $40.2 \%$ & $46.5 \%$ & $47.8 \%$ \\
\hline Consumer services & $33.1 \%$ & $51.5 \%$ & $21.7 \%$ & $28.6 \%$ & $44.3 \%$ & $50.0 \%$ & $50.2 \%$ & $48.5 \%$ & $42.4 \%$ & $51.5 \%$ & $51.5 \%$ \\
\hline Financial services & $30.8 \%$ & $52.4 \%$ & $23.4 \%$ & $35.9 \%$ & $47.5 \%$ & $48.9 \%$ & $51.7 \%$ & $52.4 \%$ & $45.0 \%$ & $50.2 \%$ & $52.4 \%$ \\
\hline Tecnology and communications & $48.9 \%$ & $65.2 \%$ & $29.2 \%$ & $36.8 \%$ & $60.9 \%$ & $62.3 \%$ & $64.7 \%$ & $65.2 \%$ & $54.7 \%$ & $65.2 \%$ & $63.5 \%$ \\
\hline Total & $32.5 \%$ & $49.4 \%$ & $21.2 \%$ & $30.5 \%$ & $42.9 \%$ & $46.7 \%$ & $48.5 \%$ & $48.9 \%$ & $41.8 \%$ & $48.2 \%$ & $49.2 \%$ \\
\hline \multicolumn{12}{|l|}{ Panel B: Temporal evolution } \\
\hline Year & & & & & & & & & & & \\
\hline 2004 & $33.2 \%$ & $47.1 \%$ & $9.8 \%$ & $15.5 \%$ & $41.9 \%$ & $45.2 \%$ & $45.7 \%$ & $46.3 \%$ & $37.3 \%$ & $46.2 \%$ & $47.1 \%$ \\
\hline 2005 & $33.5 \%$ & $48.3 \%$ & $13.5 \%$ & $20.5 \%$ & $42.3 \%$ & $45.6 \%$ & $47.4 \%$ & $47.8 \%$ & $39.2 \%$ & $47.6 \%$ & $48.0 \%$ \\
\hline 2006 & $32.2 \%$ & $48.6 \%$ & $17.0 \%$ & $24.1 \%$ & $42.3 \%$ & $45.7 \%$ & $48.0 \%$ & $48.1 \%$ & $41.3 \%$ & $47.8 \%$ & $48.3 \%$ \\
\hline 2007 & $30.8 \%$ & $49.7 \%$ & $26.3 \%$ & $35.7 \%$ & $43.8 \%$ & $47.3 \%$ & $48.6 \%$ & $49.1 \%$ & $43.9 \%$ & $48.6 \%$ & $49.7 \%$ \\
\hline 2008 & $32.4 \%$ & $51.7 \%$ & $28.7 \%$ & $41.4 \%$ & $44.8 \%$ & $48.1 \%$ & $51.0 \%$ & $51.4 \%$ & $44.2 \%$ & $50.0 \%$ & $51.4 \%$ \\
\hline 2009 & $33.3 \%$ & $50.6 \%$ & $30.5 \%$ & $43.9 \%$ & $42.2 \%$ & $48.0 \%$ & $50.2 \%$ & $50.4 \%$ & $44.3 \%$ & $48.9 \%$ & $50.6 \%$ \\
\hline
\end{tabular}


Table 2A

Auditing committee: Independent chair

Percentage of firms where the chair of the auditing committee is an independent director as declared by firms in their Annual Report on Corporate Governance and after the 8 criteria of independence described in Table 2. The grouping by size according their market capitalization is the following: companies in the Ibex35 stock market index are of December each year. "Large" firms are those non Ibex35 with average market capitalization above $€ 1000$ Million over the last three years. Medium capitalization is for firms smaller than $€ 1000$ Million but larger than $€ 250$ Million on average over the last three years. Small refers to firms with capitalizations below $€ 250$ Million on average over the last three years. The industrial sector classification is of the Spanish Stock Exchange. Data for a pool of 118 firms in 2004, 119 firms in 2005, 126 in 2006, 135 for 2007, 130 during 2008, and 124 in 2009. These are companies listed in the main trading mechanism of the Spanish Stock Exchange (SIBE).

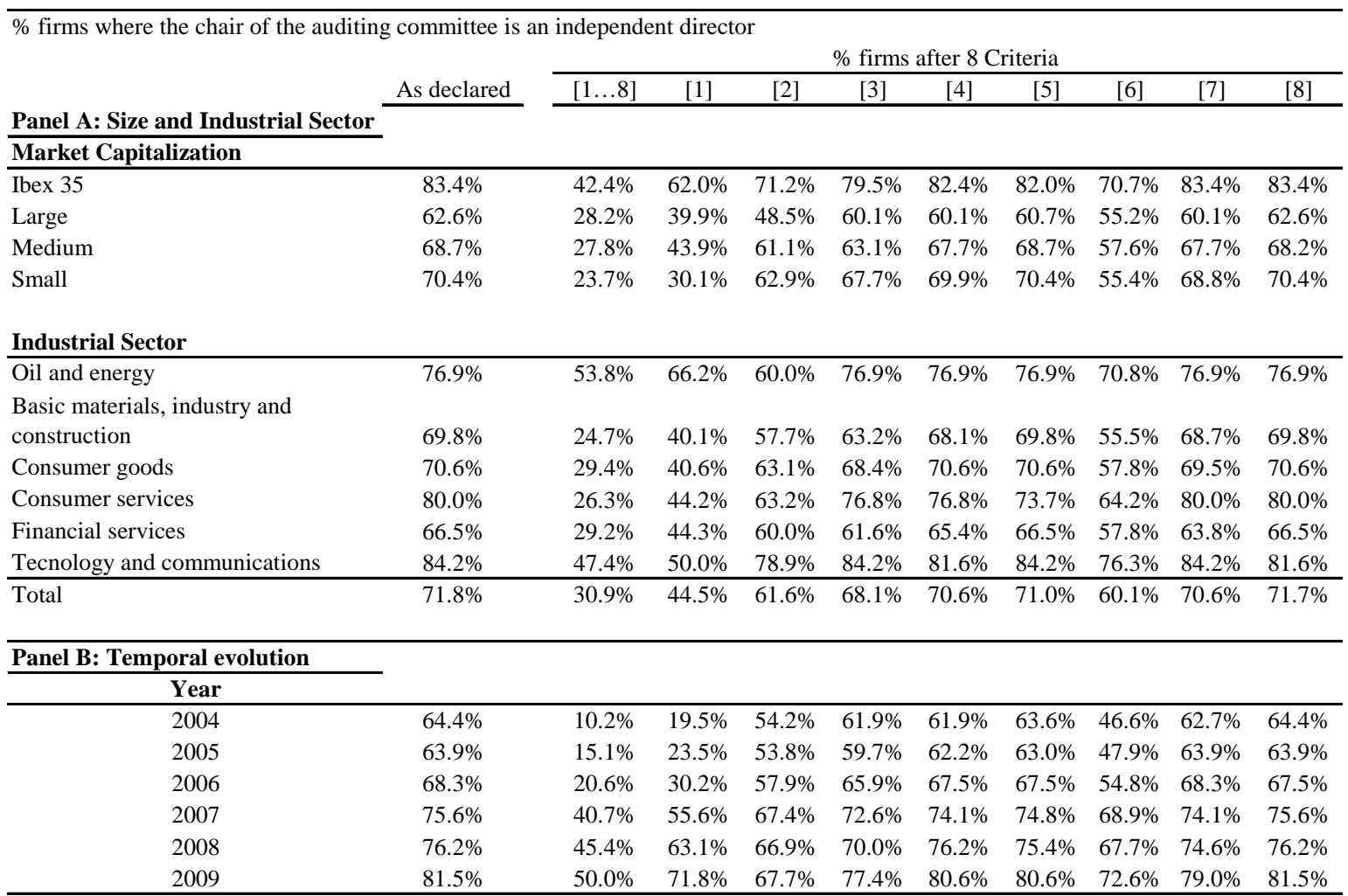


Table 3A

Nomination and remuneration committee: Proportion of independent directors

Average percentage of independent directors on the board of directors and in the nomination and remuneration committee, as declared by firms in their Annual Report on Corporate Governance and after the 8 criteria of independence described in Table 2. The grouping by size according their market capitalization is the following: companies in the Ibex35 stock market index are of December each year. "Large" firms are those non Ibex35 with average market capitalization above $€ 1000$ Million over the last three years. Medium capitalization is for firms smaller than $€ 1000$ Million but larger than $€ 250$ Million on average over the last three years. Small refers to firms with capitalizations below $€ 250$ Million on average over the last three years. The industrial sector classification is of the Spanish Stock Exchange. Average percentage of independent directors on the board is computed on the same firms as in table 2A. Several firms do not have a nomination and remuneration committee, percentages on this committee are based just on firms having it: 89 firms in 2004, 91 in 2005, 102 in 2006, 126 in 2007, 121 in 2008, and 118 in 2009. These are companies listed in the main trading mechanism of the Spanish Stock Exchange (SIBE).

\begin{tabular}{|c|c|c|c|c|c|c|c|c|c|c|c|}
\hline \multicolumn{12}{|l|}{ Average \% Independent directors } \\
\hline & Board & $\begin{array}{c}\text { Nomination and } \\
\text { remuneration } \\
\text { committee }\end{array}$ & {$[1 \ldots 8]$} & {$[1]$} & {$[2]$} & [3] & [4] & [5] & {$[6]$} & {$[7]$} & [8] \\
\hline \multicolumn{12}{|c|}{ Panel A: Size and Industrial Sector } \\
\hline \multicolumn{12}{|l|}{$\overline{\text { Market Capitalization }}$} \\
\hline Ibex 35 & $39.3 \%$ & $58.8 \%$ & $28.0 \%$ & $44.7 \%$ & $49.0 \%$ & $53.4 \%$ & $58.5 \%$ & $57.6 \%$ & $48.5 \%$ & $58.1 \%$ & $58.8 \%$ \\
\hline Large & $26.9 \%$ & $41.4 \%$ & $20.5 \%$ & $26.3 \%$ & $35.0 \%$ & $39.6 \%$ & $41.4 \%$ & $40.4 \%$ & $35.8 \%$ & $39.2 \%$ & $41.4 \%$ \\
\hline Medium & $29.8 \%$ & $49.3 \%$ & $23.7 \%$ & $37.0 \%$ & $39.9 \%$ & $43.0 \%$ & $48.2 \%$ & $49.3 \%$ & $42.7 \%$ & $49.0 \%$ & $49.0 \%$ \\
\hline Small & $32.9 \%$ & $49.5 \%$ & $22.8 \%$ & $29.0 \%$ & $43.9 \%$ & $48.4 \%$ & $48.1 \%$ & $49.2 \%$ & $41.9 \%$ & $48.9 \%$ & $49.5 \%$ \\
\hline \multicolumn{12}{|l|}{ Industrial Sector } \\
\hline Oil and energy & $37.6 \%$ & $48.2 \%$ & $28.4 \%$ & $34.6 \%$ & $40.0 \%$ & $47.2 \%$ & $48.2 \%$ & $48.2 \%$ & $43.1 \%$ & $46.7 \%$ & $48.2 \%$ \\
\hline $\begin{array}{l}\text { Basic materials, industry and } \\
\text { construction }\end{array}$ & $29.2 \%$ & $47.9 \%$ & $18.7 \%$ & $34.4 \%$ & $36.5 \%$ & $41.0 \%$ & $46.2 \%$ & $47.7 \%$ & $41.3 \%$ & $47.3 \%$ & $47.9 \%$ \\
\hline Consumer goods & $32.1 \%$ & $48.5 \%$ & $21.6 \%$ & $30.6 \%$ & $40.3 \%$ & $47.2 \%$ & $48.3 \%$ & $48.3 \%$ & $40.0 \%$ & $48.2 \%$ & $48.5 \%$ \\
\hline Consumer services & $33.1 \%$ & $45.1 \%$ & $22.0 \%$ & $30.6 \%$ & $37.0 \%$ & $41.4 \%$ & $44.0 \%$ & $42.2 \%$ & $36.9 \%$ & $44.3 \%$ & $45.1 \%$ \\
\hline Financial services & $30.8 \%$ & $53.9 \%$ & $27.9 \%$ & $40.7 \%$ & $48.0 \%$ & $49.5 \%$ & $53.7 \%$ & $53.2 \%$ & $46.7 \%$ & $52.2 \%$ & $53.9 \%$ \\
\hline Tecnology and communications & $48.9 \%$ & $70.9 \%$ & $37.4 \%$ & $48.5 \%$ & $68.6 \%$ & $64.2 \%$ & $70.9 \%$ & $70.9 \%$ & $57.3 \%$ & $70.2 \%$ & $70.0 \%$ \\
\hline Total & $32.5 \%$ & $50.4 \%$ & $24.1 \%$ & $35.3 \%$ & $42.4 \%$ & $46.6 \%$ & $49.8 \%$ & $49.8 \%$ & $42.7 \%$ & $49.5 \%$ & $50.4 \%$ \\
\hline \multicolumn{12}{|l|}{ Panel B: Temporal evolution } \\
\hline $\begin{array}{l}\text { Year } \\
\end{array}$ & & & & & & & & & & & \\
\hline 2004 & $33.2 \%$ & $48.7 \%$ & $15.1 \%$ & $23.7 \%$ & $42.7 \%$ & $45.5 \%$ & $48.1 \%$ & $48.0 \%$ & $36.9 \%$ & $48.0 \%$ & $48.7 \%$ \\
\hline 2005 & $33.5 \%$ & $49.7 \%$ & $18.4 \%$ & $27.7 \%$ & $42.7 \%$ & $45.3 \%$ & $49.1 \%$ & $49.4 \%$ & $40.6 \%$ & $48.9 \%$ & $49.7 \%$ \\
\hline 2006 & $32.2 \%$ & $50.3 \%$ & $18.7 \%$ & $29.9 \%$ & $42.3 \%$ & $45.5 \%$ & $49.7 \%$ & $49.8 \%$ & $42.8 \%$ & $48.9 \%$ & $49.9 \%$ \\
\hline 2007 & $30.8 \%$ & $48.3 \%$ & $26.0 \%$ & $36.0 \%$ & $40.3 \%$ & $44.6 \%$ & $47.3 \%$ & $47.4 \%$ & $43.2 \%$ & $47.5 \%$ & $48.3 \%$ \\
\hline 2008 & $32.4 \%$ & $52.6 \%$ & $30.4 \%$ & $43.3 \%$ & $44.0 \%$ & $48.9 \%$ & $52.1 \%$ & $52.0 \%$ & $45.4 \%$ & $52.0 \%$ & $52.6 \%$ \\
\hline 2009 & $33.3 \%$ & $52.6 \%$ & $31.4 \%$ & $45.3 \%$ & $42.8 \%$ & $49.0 \%$ & $52.2 \%$ & $51.7 \%$ & $45.4 \%$ & $51.4 \%$ & $52.6 \%$ \\
\hline
\end{tabular}




\section{Table 4A}

\section{Nomination and remuneration committee: Independent chair}

Percentage of firms where the chair of the nomination and remuneration committee is an independent director as declared by firms in their Annual Report on Corporate Governance and after the 8 criteria of independence described in Table 2. The grouping by size according their market capitalization is the following: companies in the Ibex35 stock market index are of December each year. "Large" firms are those non Ibex35 with average market capitalization above $€ 1000$ Million over the last three years. Medium capitalization is for firms smaller than $€ 1000$ Million but larger than $€ 250$ Million on average over the last three years. Small refers to firms with capitalizations below $€ 250$ Million on average over the last three years. The industrial sector classification is of the Spanish Stock Exchange. Several firms do not have a nomination and remuneration committee, percentages are based just on firms having it: 89 firms in 2004, 91 in 2005, 102 in 2006, 126 in 2007, 121 in 2008, and 118 in 2009. These are companies listed in the main trading mechanism of the Spanish Stock Exchange (SIBE).

\% firms where the chair of the nomination and remuneration committee is an independent director

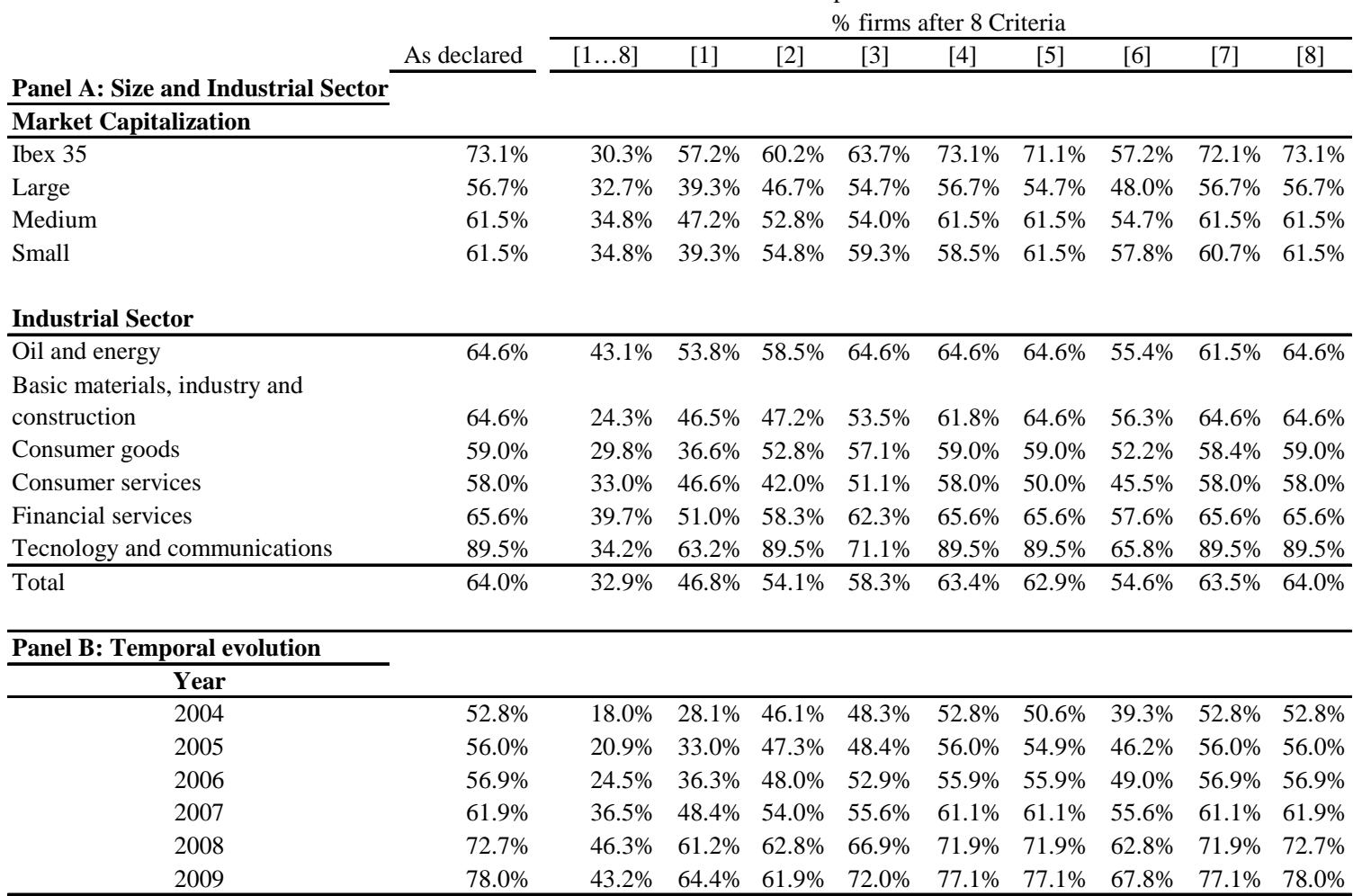

